\title{
Relative sea-level changes since 15000 cal. yr BP in the Nanortalik area, southern Greenland
}

\author{
C. J. SPARRENBOM, ${ }^{1 *}$ O. BENNIKE, ${ }^{2}$ S. BJÖRCK ${ }^{1}$ and K. LAMBECK ${ }^{3}$ \\ ${ }^{1}$ Centre for GeoBiosphere Science, Quaternary Geology, Lund University, Sweden \\ ${ }^{2}$ Geological Survey of Denmark and Greenland, Copenhagen, Denmark \\ ${ }^{3}$ Research School of Earth Sciences, Australian National University, Canberra, Australia
}

Sparrenbom, C. J., Bennike, O., Björck, S. and Lambeck, K. 2006. Relative sea-level changes since 15000 cal. yr BP in the Nanortalik area, southern Greenland. J. Quaternary Sci., Vol. 21 pp. 29-48. ISSN 0267-8179.

Received 12 January 2005; Revised 14 April 2005; Accepted 29 April 2005

\begin{abstract}
We present new results for relative sea-level change for southern Greenland for the interval from $9000 \mathrm{cal}$. yr BP to the present. Together with earlier work from the same region this yields a nearly complete record from the time of deglaciation to the present. Isolation and/or transgression sequences in one lake and five tidal basins have been identified using lithostratigraphic analyses, sedimentary characteristics, magnetic susceptibility, saturated induced remanent magnetisation (SIRM), organic and carbonate content, and macrofossil analyses. AMS radiocarbon dating of macrofossils and bulk sediment samples provides the timescale. Relative sea level fell rapidly and reached present-day level at $\sim 9300$ cal. yr BP and continued falling until at least 9000 cal. yr BP. Between 8000 and $6000 \mathrm{cal}$. yr BP sea level reached its lowest level of around $\sim 10 \mathrm{~m}$ below highest astronomical tide. At around $5000 \mathrm{cal} . \mathrm{yr} \mathrm{BP}$, sea level had reached above $7.8 \mathrm{~m}$ below highest astronomical tide and slowly continued to rise, not reaching present-day sea level until today. The isostatic rebound caused rapid isolation of the basins that are seen as distinct isolation contacts in the sediments. In contrast, the late Holocene transgressions are less well defined and occurred over longer time intervals. The late Holocene sea-level rise may be a consequence of isostatic reloading by advancing glaciers and/or an effect of the delayed response to isostatic rebound of the Laurentide ice sheet. One consequence of this transgression is that settlements of Palaeo-Eskimo cultures may be missing in southern Greenland. Copyright () 2006 John Wiley \& Sons, Ltd.
\end{abstract}

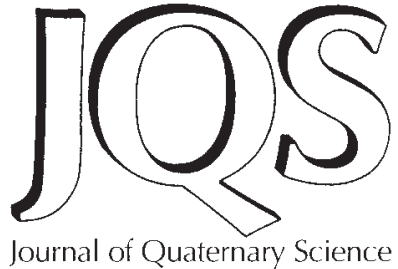

KEYWORDS: sea level; isolation basin; Lateglacial; Holocene; Greenland.

\section{Introduction}

Observations of relative sea-level changes through time provide constraints on volumes of past ice sheets as well as their retreat history, and data from different localities from around the world have been used to constrain the ice volumes of individual ice sheets as well as to establish the total change in ice volume for the Last Glacial Maximum and later times (Lambeck and Chappell, 2001). Greenland is one such ice sheet that has been investigated in this way (Fleming and Lambeck, 2004) and one that we address here. Holocene relative sea-level changes around Greenland have earlier been observed and reported in a number of investigations from different sites, for example in NE Greenland (Funder, 1978; Björck and Persson, 1981; Björck et al., 1994; Bennike and Weidick, 2001), NW Greenland (Kelly et al., 1999) and W Greenland (Rasch, 2000; Rasch and Jensen, 1997; Rasch et al., 1997; Long

* Correspondence to: Charlotte Sparrenbom, Centre for GeoBiosphere Science, Quaternary Geology, Lund University, Sölvegatan 12, 22362 Lund, Sweden. E-mail: charlotte.sparrenbom@geol.lu.se et al., 1999; Long and Roberts, 2002; Bennike, 2002; Long et al., 2003). But only limited data are available from southern Greenland (Fredskild, 1973; Funder, 1979; Bennike et al., 2002; Weidick et al., 2004) and more data are needed to be able to understand the regional postglacial sea-level changes and associated isostatic rebound in this sector.

In this paper we present results from the first of two investigations on relative sea-level changes in the southern Greenland sector. It is an extension of the shoreline displacement curve published by Bennike et al. (2002) from the Nanortalik area in which they show that the local sea level fell during the Lateglacial period and reached present level at $\sim 10000$ years ago and remained below this level until the present. In the current study we have addressed the sea-level change for the more recent period by coring five basins situated below present spring-tide sea level and one basin above this level.

Other evidence for Late Holocene relative sea-level changes in southern Greenland comes from marine geological and archaeological studies: (i) a subaerially weathered 'dry crust' found at ca. 9.3-10 m below present sea level (b.s.l.) in a core taken in Narsaq harbour dated to $>2800$ cal.yr BP (Bennike et al., 2002; Weidick et al., 2004); (ii) an undated drowned beach at 3-4 $\mathrm{m}$ b.s.l. situated close to the Norse 
settlement at Brattahlid (Kuijpers et al., 1999); and (iii) Norse and Neo-Eskimo ruins situated close to the present spring-tide water level (Mathiassen, 1936; Bak, 1969). Furthermore, from tidal measurements between 1883 and 1885, and again from 1932 to 1934, Gabel-Jørgensen and Egedal (1940) reported that the land in southern Greenland was sinking at a rate of $3.9 \pm 0.38 \mathrm{~mm}$ per year during the 48 years between the two measurements. Evidence for the presence of Palaeo-Eskimo settlements is extremely rare in southern Greenland, possibly because their areas of habitation have been inundated by the rising sea through Holocene time, and new information on regional sea-level change, especially between $4000 \mathrm{cal}$. yr BP and $250 \mathrm{cal} . \mathrm{yr} \mathrm{BP}$, may shed light upon where investigations need to be focused to find evidence of Inuit ancestors possibly reaching southern Greenland.

\section{Field area}

The Nanortalik area is situated in south Greenland (Fig. 1) at around $60^{\circ} \mathrm{N}$. The landscape is dominated by fjords reaching depths over $600 \mathrm{~m}$ and alpine mountains reaching heights of $1500 \mathrm{~m}$ near the coast and up to $2000 \mathrm{~m}$ further inland, with the ice-free land area being around $100 \mathrm{~km}$ wide. The offshore shelf is relatively narrow, mostly less than $100 \mathrm{~km}$. Glacially abraded, rounded and flattened mountains are common in the outer archipelago, especially at the mouth of the fjords. The bedrock in the region mainly consists of granites, gneissose granites, diorites, migmatised meta-sediments and meta-volcanics (Escher and Watt, 1976).

During winter, the snow cover in the Nanortalik area is deep and constant apart from windswept ridges. 'Storisen', a wide zone of drift ice following the East Greenland Current, reaches the area in late winter (ca. March) and melts off during the summer, normally disappearing from the area around late June. When the cold East Greenland Current meets the warmer Irminger Current it causes cool, cloudy and foggy conditions during the summer months with mean temperatures around $5-6^{\circ} \mathrm{C}$ at the outer coast.

Dwarf-shrub heaths with mosses and lichens dominate the vegetation. Empetrum nigrum, Betula glandulosa and Salix glauca constitute major elements in the heaths.

\section{Methods}

Fieldwork was carried out during three weeks in August 2001. A large Zodiac inflatable boat was used to transport coring

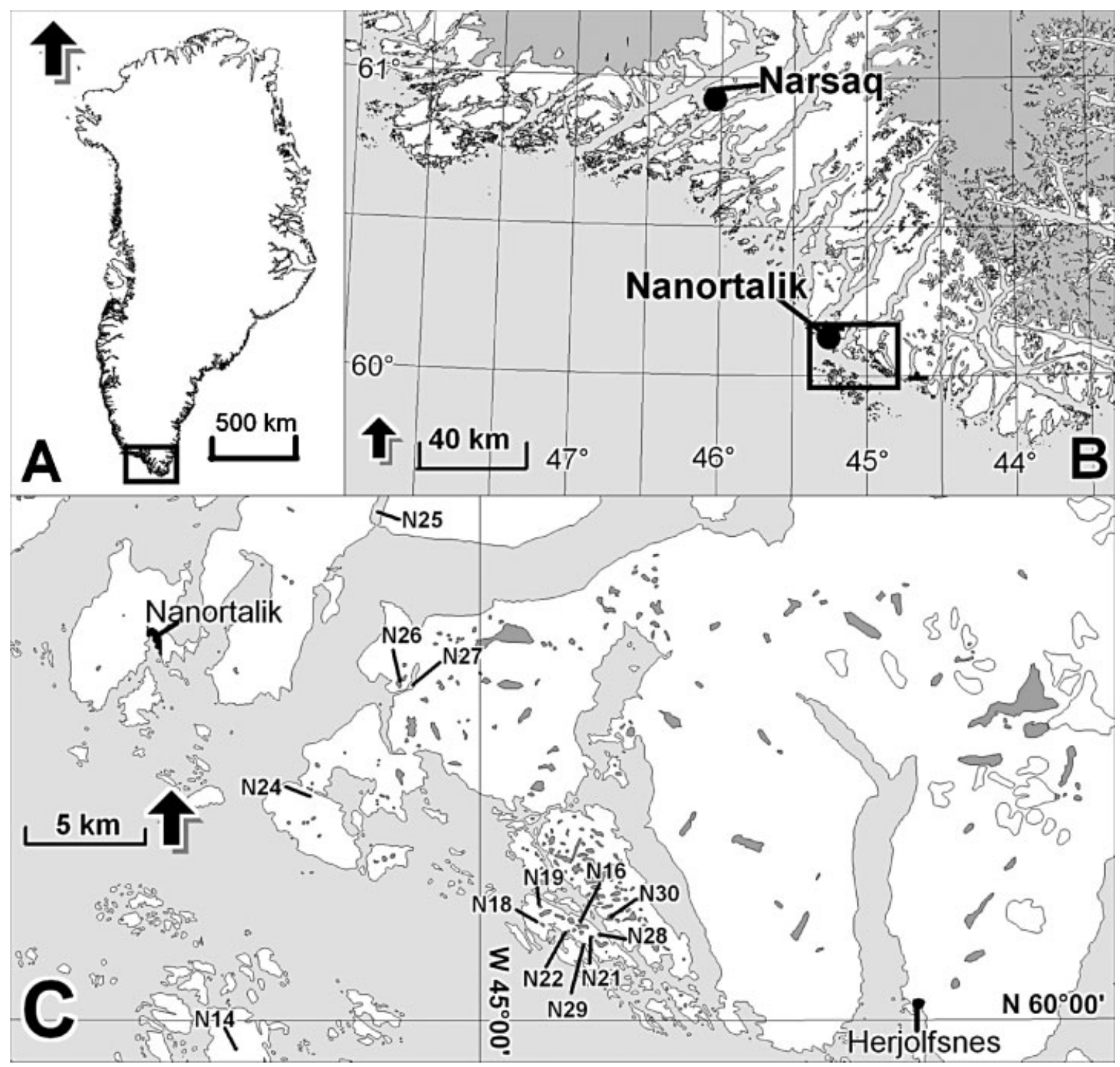

Figure 1 (A) Map of Greenland where the rectangle marks the sector where the investigated sites are located. (B) Map of the southern Greenland sector with the rectangle defines the field area. (C) Map showing the location of investigated sites (N14-N24 investigated in 1999 (Bennike et al., 2002) and N25-N30 investigated in 2001) 
equipment and people from a base in Nanortalik to the different coring sites. Coring positions were determined with GPS or, in the case of sites N29 and N30, taken from the sea chart. The bathymetry of the submarine basins was investigated with an echo sounder to find suitable coring sites. A small specially designed Zodiac, with a funnel hole in the centre, was used as a coring platform. During coring, the small Zodiac was usually roped tightly to three points on the shore. Using a Russian corer, multiple overlapping core sediment sequences were collected from the different basins. The cores were described and then wrapped for shipment back to the laboratory in Lund, where the cores are stored at $4{ }^{\circ} \mathrm{C}$.

As the aim of the investigation is to establish when sea level was situated at a certain level, it is important to take tides into consideration. The marine influence in a basin will start and stop when the saline oceanic water ceases to cross the sill of the basin. The highest astronomical tide is therefore of importance, as that controls when marine waters can enter the basin. Storm events may also be of importance but harder to establish in detail, and will not affect the different sites evenly because of differences in location and exposure. The highest astronomical tide has been calculated by $\mathrm{O}$. Andersen (KMS) using the global tidal model AG (Andersen Grenoble, 1995.1) for each site and it varies between sites from $184 \mathrm{~cm}$ to $188 \mathrm{~cm}$ above mean sea level. The mean tidal amplitude for the area is ca. $0.75 \mathrm{~m}$ and $1.5 \mathrm{~m}$ at neap and spring tides, respectively (Farvandsvæsenet, 2000, 2001).

The altitude of the sill of the lake was measured with a digital altimeter and a clinometer, while the threshold levels of the tidewater basins were measured using an echo sounder and coring rods. The accuracy of the sill measurements depends on the method used (Table 1). By noting the time for every measurement, tidal corrections were possible. The total uncertainty at each site depends on: the accuracy of the measurement; the interpreted threshold development; and the uncertainty in the tidal correction. The total uncertainty is then the square root of the sum of the variances of the three contributing factors, i.e.

$$
\sigma_{\text {total }}=\left(\sigma_{1}^{2}+\sigma_{2}^{2}+\sigma_{3}^{2}\right)^{1 / 2}
$$

where $\sigma_{1}^{2}$ is the measurement variance, $\sigma_{2}^{2}$ is the variance of the threshold development and $\sigma_{3}^{2}$ is the variance of the tidal correction. The total uncertainty of the relative sea-level determination for each site is given in Table 1.

Detailed lithological descriptions were carried out in the laboratory before subsampling. Measurements of magnetic susceptibility and saturation isothermal remanent magnetisation (SIRM), organic and carbonate contents were carried out on closely spaced samples from all cores. The magnetic susceptibility $(\chi)$ is a measure of the extent to which a sediment can be magnetised and is expressed as $\left(\mu \mathrm{m}^{3} \mathrm{~kg}^{-1}\right)$, and depends on the mineral composition of the sediment. High susceptibility values may indicate a higher content of magnetic particles, i.e. a sediment containing more minerogenic particles, and low values may indicate the absence of magnetic particles, i.e. often a more organic sediment. However, this is a simplification since the magnetic susceptibility may also be a measure of the amount of magnetotactic bacteria. The measurement on naturally wet samples is particularly useful to facilitate core correlations, but in combination with SIRM it is also a supplementary method to recognise isolation events, i.e. changes in depositional environment (Björck, 1979). The susceptibility measurements were made with a Geofyzika Brno KLY-2 susceptibility bridge on naturally wet samples.

A Redcliff pulse-magnetiser (model 700 BSM) has been used to induce a field of $1 \mathrm{~T}$ to achieve saturation isothermal remanent magnetisation, and a Molspin Minispin spinner magnetometer was used to measure the remanent magnetisation. SIRM was measured on naturally wet sediment as well as on sediments that were dried at $55^{\circ} \mathrm{C}$ for $12-24 \mathrm{hr}$. The authigenically formed magnetic mineral gregite $\left(\mathrm{Fe}_{3} \mathrm{~S}_{4}\right)$ forms in anoxic environments in fresh, marine or brackish water where sulphate supply is limited (Walden et al., 1999; Sandgren and Snowball, 2001). It can be expected in isolation sequences when the environment changes from marine aerobic conditions to brackish anaerobic conditions.

Analyses of plant and animal macrofossils were used to check the interpretations of environmental changes, particularly isolations/transgressions, implied by the other analyses. Samples for macrofossil analyses were wet-sieved using a 0.2-mm sieve.

AMS radiocarbon dating was carried out on selected terrestrial or freshwater macrofossils and bulk sediment samples where suitable macrofossils were not found. The radiocarbon dating was carried out at the Radiocarbon Dating Laboratory in Lund and the Poznan Radiocarbon Laboratory. The radiocarbon dates were calibrated using the software Oxcal v. 3.5 (Bronk Ramsey, 2001) and v. 3.9 (minor changes in 2003), based on the INTCAL98 dataset of Stuiver et al. (1998), and using the terrestrial calibration curve. The radiocarbon analyses provide ages for the time of isolation and transgression of each basin.

\section{Results}

The six investigated sites are described below. We continue to use site name codes from Bennike et al. (2002), where N stands for Nanortalik. Sediment depths in the descriptions refer to depth below water surface. Altitude of the thresholds are related to metres above $(+)$ or below $(-)$ the highest astronomical tide ( $\mathrm{m}$ a.h.a.t. and $\mathrm{m}$ b.h.a.t., respectively).

\section{Tidal basin N25 $\left(\mathrm{N} 60.1896^{\circ}, \mathrm{W} 45.0760^{\circ}\right)$}

The site is a marine tidal basin with a threshold consisting of a coarse sediment lag (pebbles and rocks) at $6.3 \mathrm{~m}$ b.h.a.t. The

Table 1 Assessment of total uncertainty for each site investigated in 2001

\begin{tabular}{|c|c|c|c|c|c|c|}
\hline Site & $\begin{array}{c}\text { Measured } \\
\text { elevation (m a.m.s.l.) }\end{array}$ & $\begin{array}{l}\text { Measurement } \\
\text { method }\end{array}$ & $\begin{array}{l}\text { Measurement } \\
\text { uncertainty }(\mathrm{m})\end{array}$ & $\begin{array}{l}\text { Assessment of } \\
\text { threshold uncertainty }(\mathrm{m})\end{array}$ & $\begin{array}{c}\text { Tidal } \\
\text { uncertainty }(\mathrm{m})\end{array}$ & $\begin{array}{c}\text { Total } \\
\text { uncertainty }(\mathrm{m})\end{array}$ \\
\hline N25 & -4.5 & Rods & 0.1 & \pm 0.3 & 0.5 & \pm 0.6 \\
\hline N26 & 5 & Clinometer & 0.2 & \pm 0.1 & 0.5 & \pm 0.5 \\
\hline N27 & -0.45 & Rods & 0.1 & \pm 0.0 & 0.5 & \pm 0.5 \\
\hline N28 & -5.95 & Rods & 0.1 & $+1 /-2$ & 0.5 & $+1.1 /-2.1$ \\
\hline N29 & -1.45 & Rods & 0.1 & $+1 /-2$ & 0.5 & $+1.1 /-2.1$ \\
\hline N30 & 1.25 & Rods & 0.1 & \pm 0.3 & 0.5 & \pm 0.6 \\
\hline
\end{tabular}


basin is located $10 \mathrm{~km}$ northeast of Nanortalik in the Tasermiut fjord and is the most inland site investigated to yield isolation or transgression results. It is oval in shape, ca. $1500 \mathrm{~m}$ long and $400 \mathrm{~m}$ wide, and a series of lakes drain into it via a waterfall. The water depth at the coring site varies with the tides, between $9.5 \mathrm{~m}$ and $11 \mathrm{~m}$, but in some parts of the basin, depths of up to $22 \mathrm{~m}$ were recorded. At the isolation contact at $1200 \mathrm{~cm}$, the sediments change from greenish grey sandy clayey gyttja silt, into laminated greyish brown sandy clayey algal-rich silt gyttja (Fig. 2). Marine algae, foraminifera and Mytilus edulis also disappear above this level and a freshwater fauna with Cladocera and Chironomidae start to dominate (Fig. 3). The organic car- bon and carbonate content increase at around $1200 \mathrm{~cm}$ and a small peak is visible in all the magnetic parameters (Fig. 2). The transgression event is harder to establish from the lithological analyses alone as there are several possibilities indicated by the sedimentary changes and changes in the magnetic parameters, as well as by the organic carbon and carbonate content at $1181 \mathrm{~cm}, 1163.5 \mathrm{~cm}, 1078 \mathrm{~cm}, 1061 \mathrm{~cm}, 1044.5 \mathrm{~cm}$ and $1027 \mathrm{~cm}$. But from the macrofossil analyses the transgression can be established at $1061 \mathrm{~cm}$ (Fig. 3). The transgression is a more gradual transition than the isolation event, with freshwater taxa such as Isoëtes lacustris, Rhabdocoela and Cladocera slowly decreasing in numbers while marine algae,

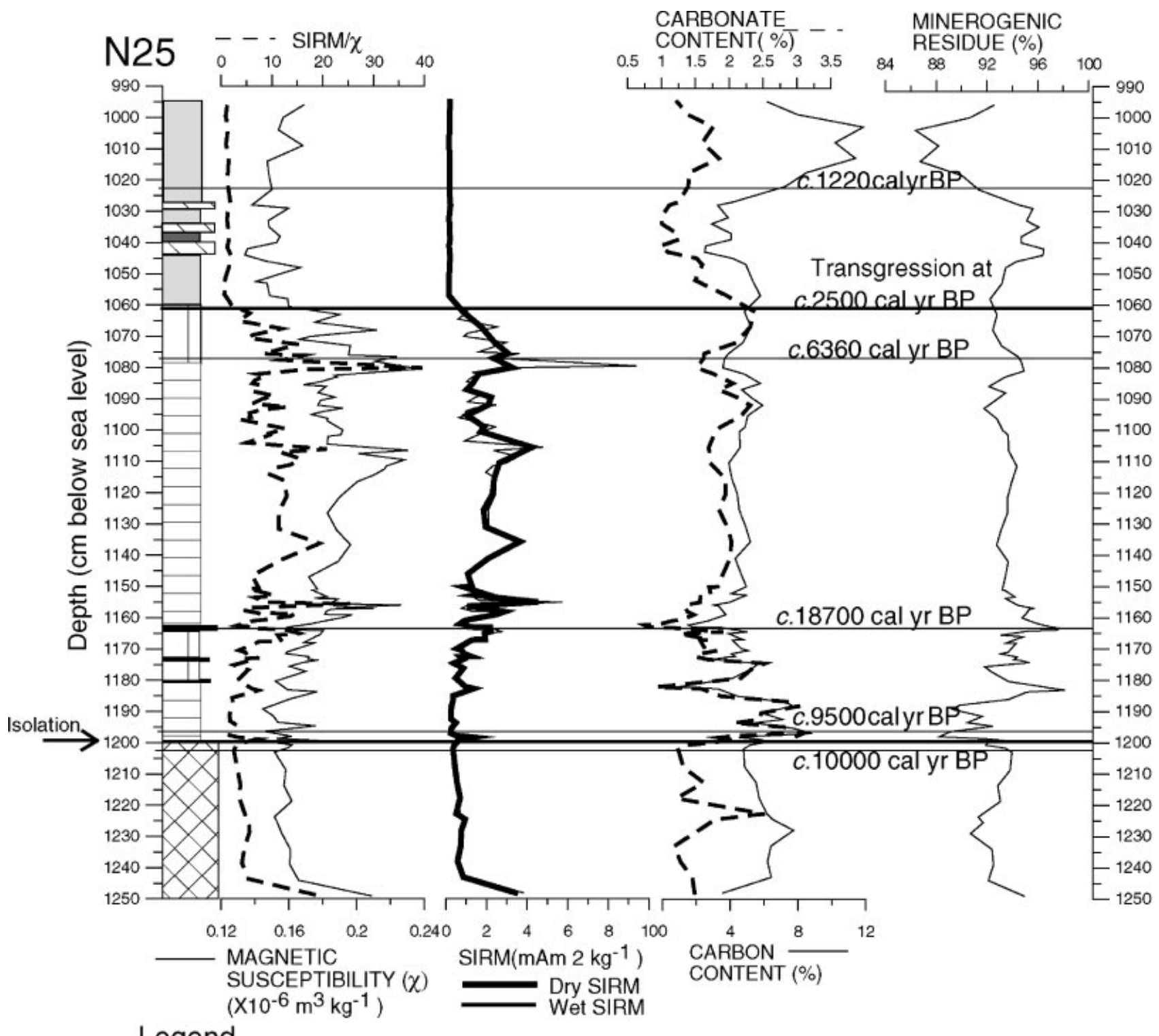

Legend

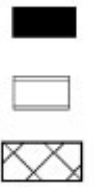

silty and sandy silty gyttja clay or clayey silt sandy clayey algae-rich silt gyttja, laminated with grey/black FeS-bands sandy clayey gyttja silt

clayey silty sand gyttja clayey silty gyttja sand sandy clayey algae-rich silt gyttja or clayey silty algae-rich sand gyttja sandy silty algae-rich clay gyttja, laminated with grey/black FeS-bands

Figure 2 Core log for site N25, the magnetic susceptibility, SIRM/ $\chi$ (scale bar on top), SIRM wet and dry, carbon content (mass\% of dry weight), carbonate contents (mass\% of dry weight, scale bar on top) and minerogenic residue (mass\% of dry weight). Ages given are calibrated years BP (cal. yr BP) or interpreted interpolated ages between several dates, all in cal. yr BP 


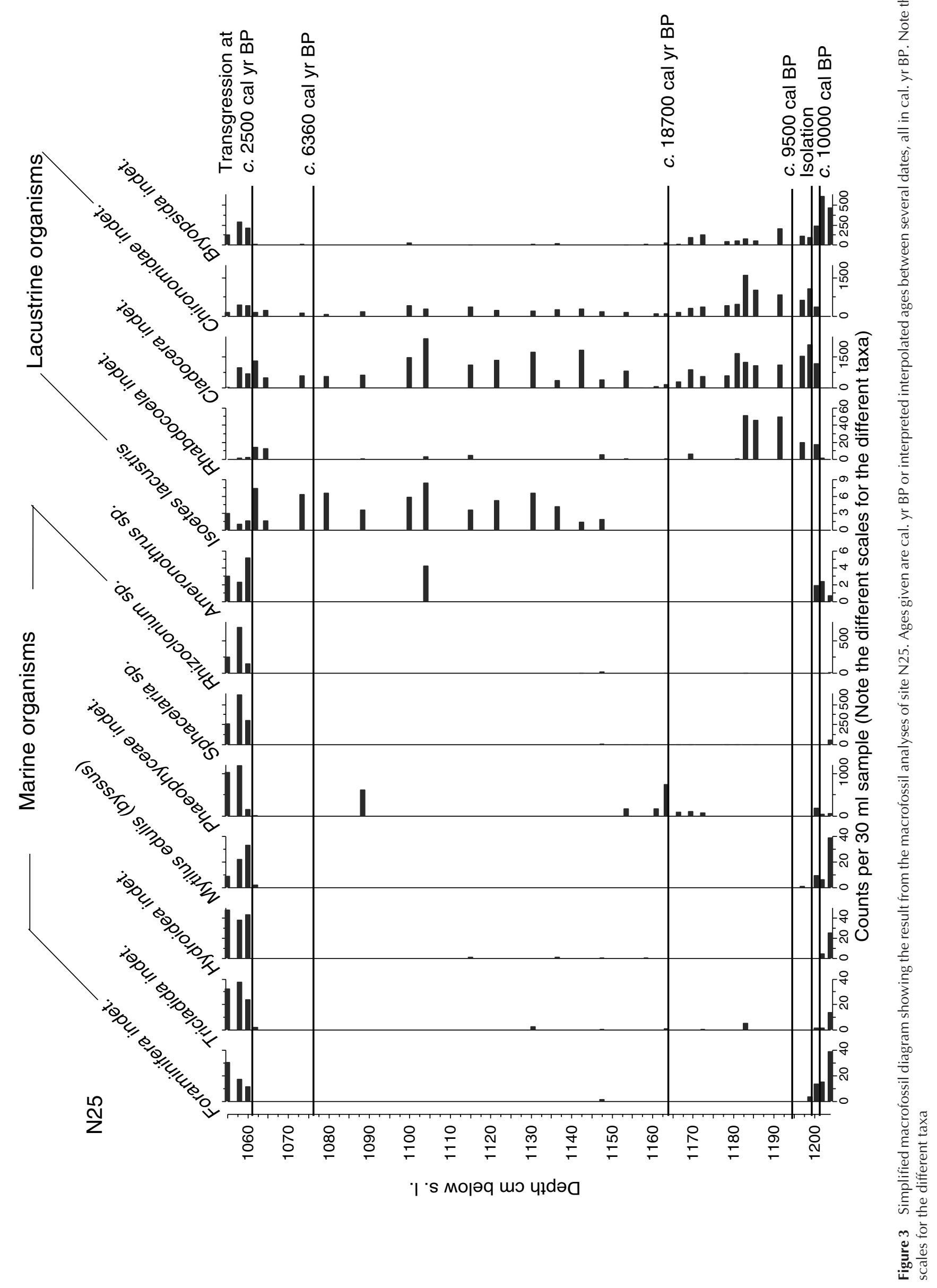


Foraminifera and Mytilus edulis increase in numbers at the same time. The small number of poorly preserved marine macrofossils appearing in the interval between $1200 \mathrm{~cm}$ and $1063 \mathrm{~cm}$ can possibly be explained by wave-induced erosion and re-sedimentation of older sediments. The presence of reworked material is supported by the old radiocarbon age of $15690 \pm 90{ }^{14} \mathrm{C}$ yr BP for a bulk sediment sample from $11.635 \mathrm{~cm}$ (Poz-7175, Table 2). Alternatively, the occurrence of marine macrofossils in small numbers during periods clearly dominated by freshwater species may be a result of storm events that transported marine waters and organisms over the relatively narrow and low threshold which is located towards the south-southwest and is exposed to southwesterly storms. The age of the isolation of the basin is determined to around $9500 \mathrm{cal} . y r$ BP based on a bulk sediment sample (94709630 cal. yr BP) just above the isolation contact, a macrofossil sample of Nitella sp. (9020-9490 cal.yr BP) at and above the isolation contact and a sample of the moss Drepanocladus cf. badius (9750-10490 cal.yr BP) just below the contact (Table 2). The time of the transgression is dated to around 2500 cal. yr BP based on a sample of the following taxa; Bryopsida indet., Nitella sp., Empetrum sp., Isoëtes lacustris, Daphnia pulex, Batrachium confervoides and chironomids (23402740 and 2150-2250 cal. yr BP) at 1057-1061 cm (Table 2).
Lake N26 (N $\left.60.1278^{\circ}, \mathrm{W} 45.0621^{\circ}\right)$

The lake is located ca. $9 \mathrm{~km}$ east of Nanortalik close to the mountain Jakobinerhuen at the mouth of Tasermiut fjord. The threshold consists of rock at an altitude of ca. $3.2 \mathrm{~m}$ a.h.a.t. With an irregular shape, the basin measures ca. $150 \times 500 \mathrm{~m}$. There is no obvious inlet to the lake, so inflow of material is limited to that brought by surface runoff. The water depth at the coring site is $5.5 \mathrm{~m}$, but depths of up to $10 \mathrm{~m}$ were recorded in the basin. Sedimentary changes from brownish grey silty sand to dark brown and black FeS-laminated sandy clayey algal-rich silt gyttja overlain by clayey silt gyttja can be observed around the isolation (Fig. 4). Marine algae, Hydroidea indet. and Mytilus edulis disappear at the isolation and a freshwater fauna with the cladocerans Daphnia sp. and Ceriodaphnia sp. and chironomids appear and increase in abundance (Fig. 5). Organic carbon and carbonate content increase at the same level (Fig. 4). SIRM and susceptibility also increase during the transition from the marine to the freshwater environment at 920 to $915 \mathrm{~cm}$. The age of the isolation is established to ca. $10300 \mathrm{cal}$. yr BP on the basis of three bulk sediment samples (one at $916-918 \mathrm{~cm}$ with the age of 9900$10650 \mathrm{cal} . \mathrm{yr} \mathrm{BP}$, one at $914-916 \mathrm{~cm}$ dated to 9900 $10600 \mathrm{cal} . \mathrm{yrBP}$ and one at $910-914 \mathrm{~cm}$ with an age of

Table 2 AMS radiocarbon and calibrated dates for sites N25-N30

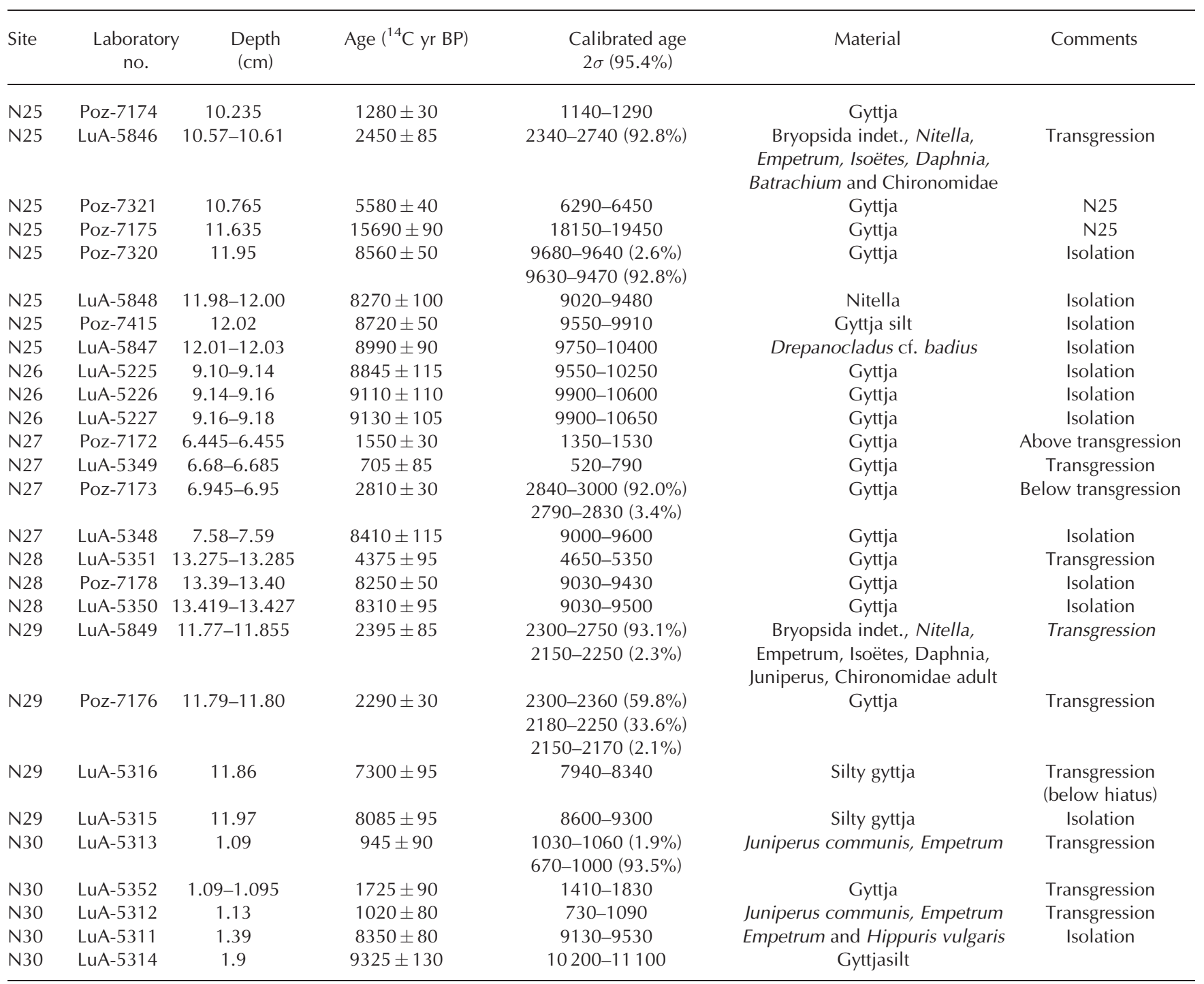




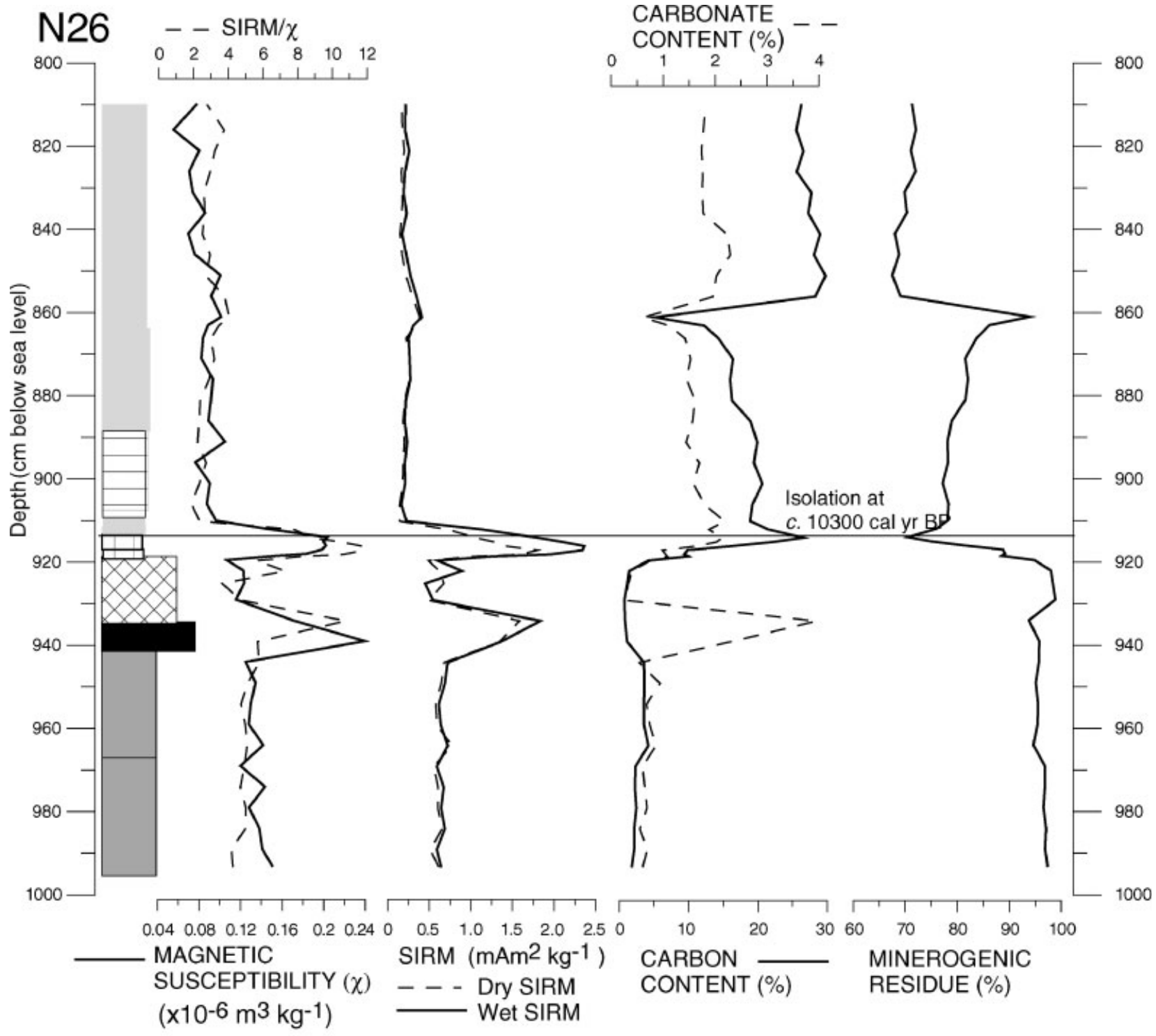

\section{Legend}

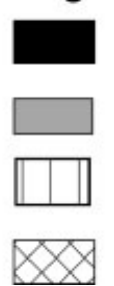

silty gravelly sand silty sandy gravel

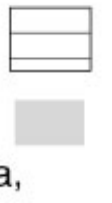

laminated silty clayey algae gyttja sandy clayey silt sandy clayey algae-rich gyttja, algae gyttja containing various proportions of silt and clay laminated with FeS-bands

\section{silty sand}

Figure 4 Core log for site N26, the magnetic susceptibility, SIRM/ $\chi$ (scale bar on top), SIRM wet and dry, carbon contents (mass $\%$ of dry weight), carbonate contents (mass\% of dry weight, scale bar on top) and minerogenic residue (mass\% of dry weight). Ages given are cal. yr BP or interpreted interpolated ages between several dates

9550-10250 cal. yr BP, Table 2) at the transition between the two sedimentation environments.

\section{Tidal basin $\mathrm{N} 27\left(\mathrm{~N} 60.1321^{\circ}, \mathrm{W} 45.0513^{\circ}\right)$}

The site is a tidal basin located ca. $9 \mathrm{~km}$ east of Nanortalik close to site N26 and the mountain Jakobinerhuen at the mouth of the Tasermiut fjord. Bare bedrock constitutes the threshold at an altitude of $2.3 \mathrm{~m}$ b.h.a.t. A series of lakes drain into this ovalshaped basin. The basin measures ca. $1250 \times 160 \mathrm{~m}$. The water depth at the coring site is ca. $6 \mathrm{~m}$, but in some parts of the basin, depths of up to $15 \mathrm{~m}$ were recorded. Today the environment in the basin changes twice a day because of the tides, from being part of the sea to becoming an isolated water body.

Below the isolation found at ca. $757-759 \mathrm{~cm}$, the sediments consist of greyish gyttja with gravel and sand, changing into laminated brown gyttja containing black iron sulphide-rich laminae (Fig. 6). Above the isolation contact, laminated gyttja continues another ca. $5 \mathrm{~cm}$, with colours that vary from reddish to more greyish brown. Marine brown algae, Mytilus edulis and Tricladida indet. disappear above the isolation and a freshwater fauna with Cladocera especially Daphnia sp., Chironomidae and Plumatella sp. starts to dominate (Fig. 7). The organic carbon and carbonate content increase below 


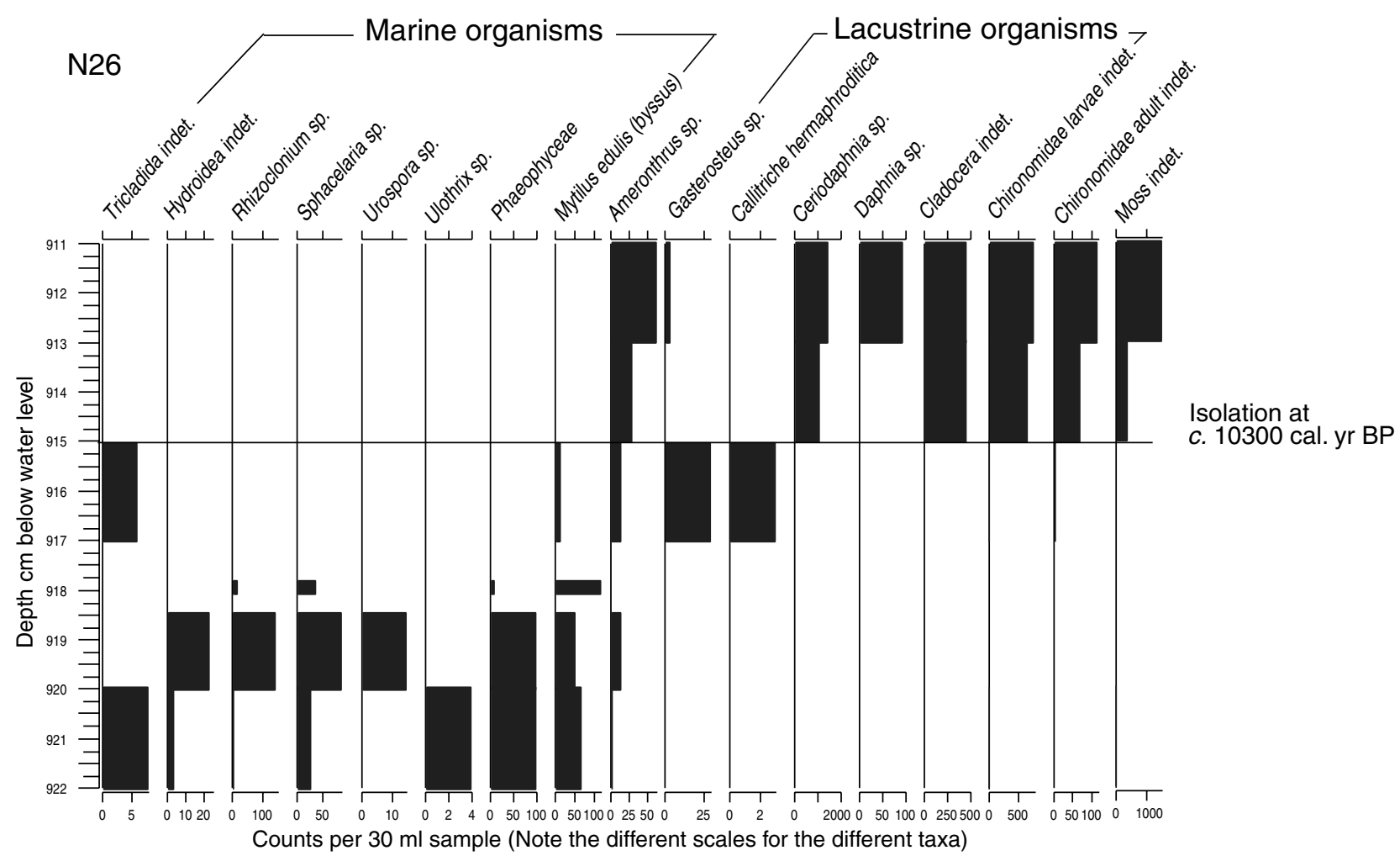

Figure 5 Simplified macrofossil diagram showing the results from the macrofossil analyses of site N26. Ages given are cal. yr BP or interpreted interpolated ages between several dates, all in cal. yr BP. Note the different scales for the different taxa

the isolation contact, probably as a consequence of the threshold reaching above the low tide level and the basin becoming 'semi-isolated', i.e. isolated during low tides twice a day resulting in brackish water conditions. Both the organic and the carbonate content are rather high during the isolation phase compared to the marine environment before the isolation. The magnetic susceptibility curve shows a small rise at the isolation and decreases above the contact at ca. $750 \mathrm{~cm}$ (Fig. 6). The magnetic susceptibility varies as a consequence of the concentration of magnetic particles, which is mostly controlled by the variation of the minerogenic content. Figure 6 shows that susceptibility values increase and decrease when the minerogenic residue increases and decreases, respectively.

The sedimentary transition from a freshwater environment into a marine environment at the transgression (level $669 \mathrm{~cm}$ ) is reflected by a change from dark brown algae gyttja into a brown, green, and grey laminated algae gyttja with marked black iron sulphide lamination (Fig. 6). All the magnetic parameters measured show a marked decrease at this level. Carbon and carbonate content show large fluctuations, probably as a result of the constantly changing environment due to saltwater inflow twice a day. Foraminifera, Hydroidea and some brown algae enter the basin while the freshwater taxa Cladocera, Chironomidae and Isoëtes lacustris slowly decrease in numbers (Fig. 7). The age of the isolation of the basin is established to around ca. $9300 \mathrm{cal} . \mathrm{yr} \mathrm{BP}$ (Table 2) based on a bulk sediment sample at the isolation contact at $758-759 \mathrm{~cm}$ (9000$9600 \mathrm{cal} . \mathrm{yr} \mathrm{BP})$. The time of the transgression is determined to around $2100 \mathrm{cal}$. yr BP (at level $668 \mathrm{~cm}$ ) on the basis of an interpolation between two bulk sediment samples, one from above the transgression at $645 \mathrm{~cm}(1350-1530 \mathrm{cal} . \mathrm{yr} \mathrm{BP})$ and the other taken below the transgression at $694.5-695 \mathrm{~cm}$ (2840-3000 and 2790-2830 cal.yr BP) (Table 2). The uncertainty of this transgression date is hard to estimate, especially considering any marine reservoir effect, but it certainly amounts to at least a few hundred years. The error bars for this interpolated age have been set to -750 and +900 , which are the minimum and maximum departures of the measured ages of the bulk samples from the interpolated mean. A third bulk sediment sample from level $668-668.5 \mathrm{~cm}$ gave an age of $520-790$ cal. yr BP. This date is likely to be too young, as the sample above this level is older and the sample below was dated to ca. 2900 cal. yr BP.

\section{Marine embayment N28 (N 63.0316 ${ }^{\circ}$, W $44.9083^{\circ}$ )}

This marine embayment is located ca. $23 \mathrm{~km}$ southeast of Nanortalik at Narlusoq island and measures ca. $250 \times 125 \mathrm{~m}$. Bedrock or boulders form the threshold at $7.8 \mathrm{~m}$ b.h.a.t. and the maximum depth measured in the basin is $20 \mathrm{~m}$. The water depth at the coring sites varied between ca. $8.3 \mathrm{~m}$ and $12 \mathrm{~m}$ as a consequence of tidal changes during the day and shifting positions of the coring platform but the overlapping cores could be successfully correlated visually as well as with the magnetic scans. The isolation contact is placed at $1340.5-1341.5 \mathrm{~cm}$ at the transition from dark brown to black FeS-laminated silt gyttja with a high content of minerogenic material to lighter brown sandy clay algal rich silt gyttja (Fig. 8). Marine brown algae, Foraminifera, Tricladida and Hydroidea disappear above this level and a freshwater fauna with Cladocera, Chironomidae and Plumatella sp. starts to dominate (Fig. 9).

The organic carbon and carbonate contents first increase just above $1345 \mathrm{~cm}$ and continue to increase until level $1332 \mathrm{~cm}$ where they both suddenly decrease. The magnetic parameters (Fig. 8) show high peaks at the isolation contact at $1341 \mathrm{~cm}$ and then fluctuate highly until $1326 \mathrm{~cm}$ where they reach the same high values as before the isolation. The mid- to late Holocene 


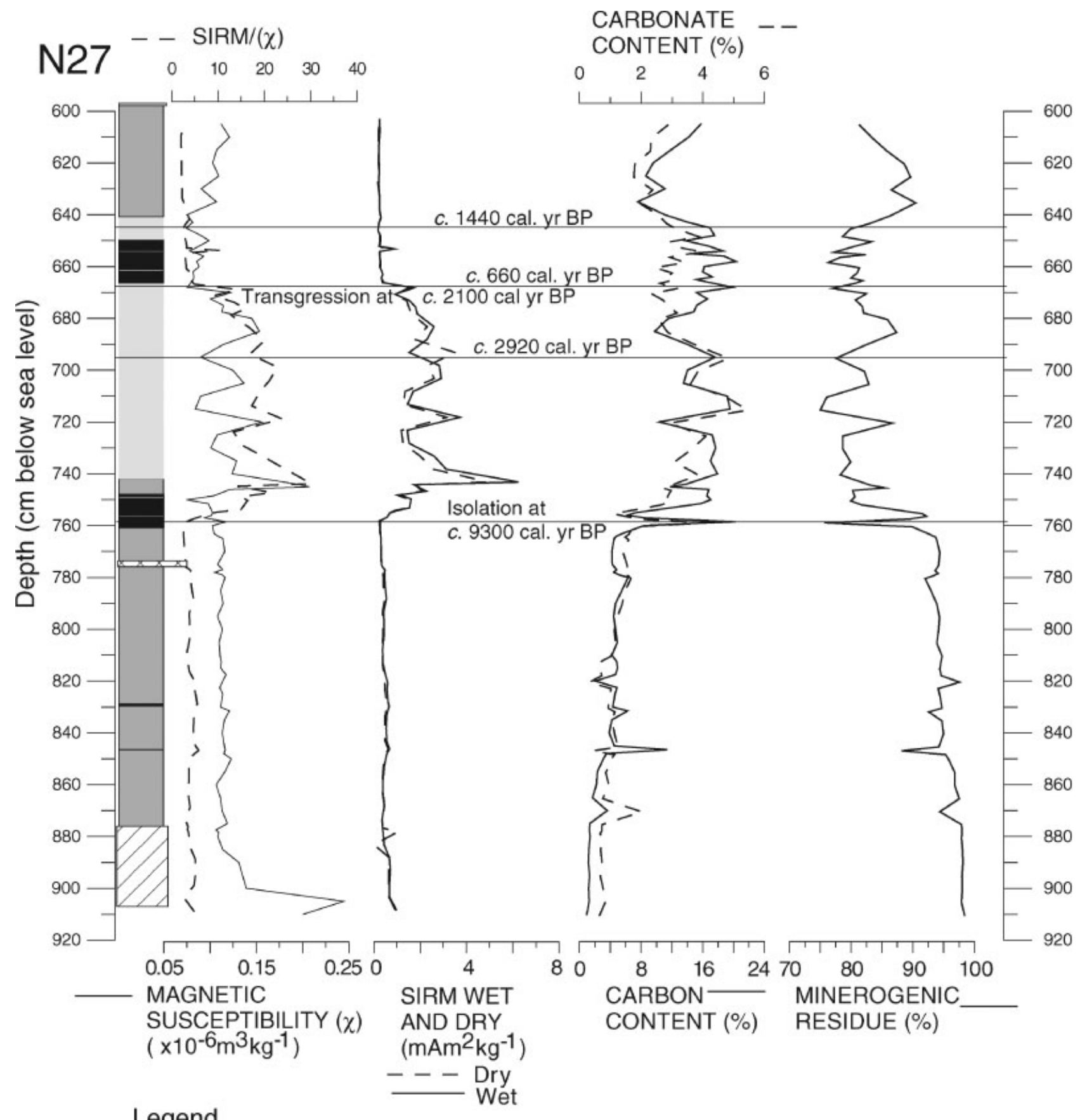

Legend

Algae gyttja with various contents of sand, silt and clay

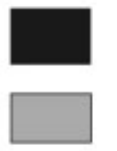

Sandy silty clayey detritus gyttja

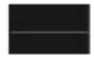

FeS laminated gyttja with various contents of sand, silt and clay

EXX Enrichment horizon Gyttja with varying contents of sand, silt and clay of sand and gravel Sandy silty clay in gyttja

Figure 6 Core log for site N27, the magnetic susceptibility, SIRM/ $\chi$ (scale bar on top), SIRM wet and dry, carbon contents (mass\% of dry weight), carbonate contents (mass \% of dry weight, scale bar on top) and minerogenic residue (mass\% of dry weight). Ages given are cal. yr BP or interpreted interpolated ages between several dates, all in cal. yr BP

transgression in south Greenland, from a freshwater environment into full marine conditions, has usually been found to be a gradual process, but in the cores from this site the lithologic change is very sharp. The freshwater sequence is only ca. $6 \mathrm{~cm}$ thick, and from the radiocarbon analyses we conclude that the sequence is incomplete and that erosion has removed significant parts of it. The first incursion of marine water into the basin is seen at $1334 \mathrm{~cm}$ on the basis of macrofossil analyses 


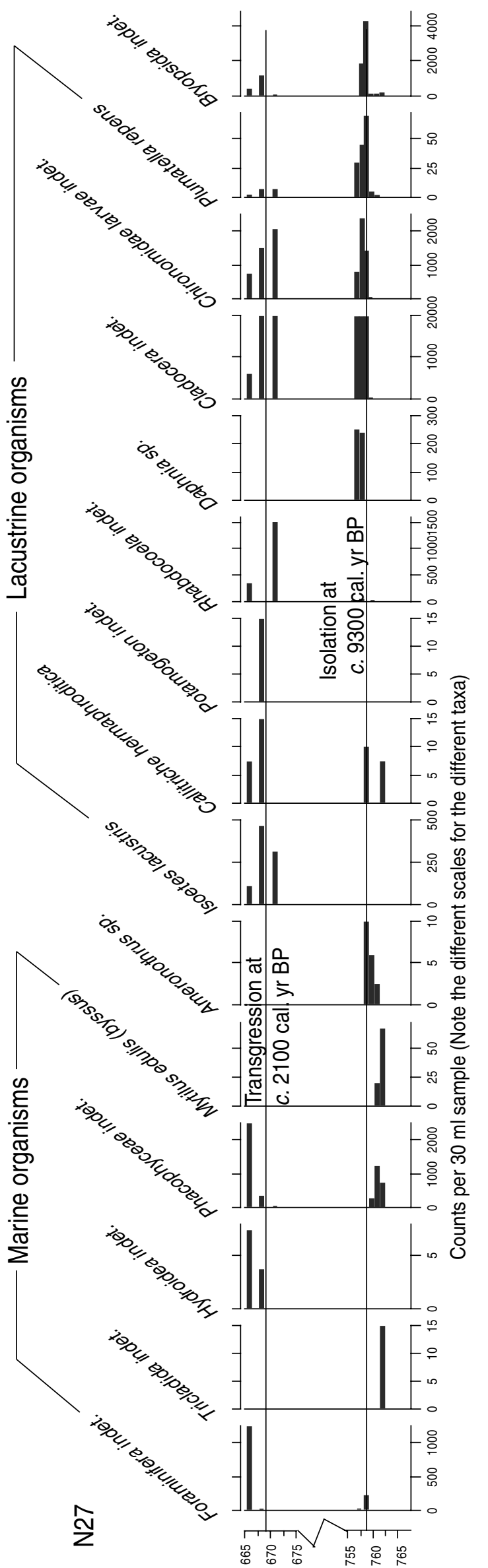

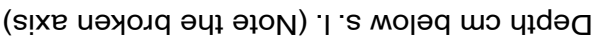

(Fig. 9). Foraminifera, Pectinaria sp. and some marine brown algae enter the basin and freshwater species such as Cladocera, Chironomidae and Plumatella sp. start a slow decline.

The isolation of the basin is dated to ca. $9250 \mathrm{cal} . \mathrm{yrBP}$ (Table 2) based on two bulk sediment samples (one above the isolation at 1339-1340 cm dated to 9030-9430 cal.yr BP and one below the isolation at 1341.9-1342.7 cm dated to 9030$9500 \mathrm{cal} . \mathrm{yr} \mathrm{BP})$. The time of the transgression is determined to have occurred before $5000 \mathrm{cal}$.yr BP based on a marine bulk sediment sample taken at $1327.5-1328.5 \mathrm{~cm}$ (Table 2). This date presents a minimum age of the transgression event as it is taken above the hiatus in marine sediments. The transgression must therefore have started at this time or earlier.

\section{Tidal basin N29 $\left(\mathrm{N} 60.0300^{\circ}, \mathrm{W} 44.9303^{\circ}\right)$}

The threshold of this ca. $300 \times 250 \mathrm{~m}$ marine embayment is made up of boulders located $3.3 \mathrm{~m}$ b.h.a.t. It is located ca. $23 \mathrm{~km}$ southeast of Nanortalik by Narlusoq island and the maximum depth measured in the basin is $22 \mathrm{~m}$. As a consequence of tidal changes during the day and horizontal movements of the coring platform between each coring, water depth varied between ca. 11.6 and $12.8 \mathrm{~m}$. The isolation contact is placed at $1197.5 \mathrm{~cm}$, at the transition from light greyish brown sandy clayey silty gyttja to brown, black and grey laminated sandy clayey silty gyttja with FeS laminae (Fig. 10). At this level, marine algae, foraminifera, Tricladida and Hydroidea disappear and freshwater organisms with Cladocera, Chironomidae and Nitella sp. start to dominate (Fig. 11). The organic carbon content first increases just below the isolation contact at ca. $1203 \mathrm{~cm}$ and continues a general increase until ca. $1194 \mathrm{~cm}$ where it suddenly decreases. The carbonate curve has roughly the same shape as the carbon curve, except between 1200$1207 \mathrm{~cm}$ where there is a high peak in the carbonate curve corresponding to a high concentration of shell fragments (Fig. 10). The magnetic parameters (Fig. 10) decrease from around the isolation with a high peak just above the onset of marine conditions at $1185.5 \mathrm{~cm}$. The lithology at the assumed lacustrinemarine transition shows a sharp erosive contact and the brown, black and grey laminated sandy clayey silty gyttja containing FeS-(bands) laminations changes abruptly into a brownish grey sandy silt gyttja. Two ${ }^{14} \mathrm{C}$-dated bulk samples confirm the erosive contact; the sample below the contact at $1186 \mathrm{~cm}$ has an age of ca. 8140 cal. yr BP and the sample above was dated to ca. 2300 cal. yr BP (Table 2). The macrofossil analyses show a fairly abrupt change from freshwater taxa to marine taxa, compared to most of the other sites; from an environment dominated by Cladocera, Chironomidae and Nitella sp. to an environment dominated by marine algae, foraminifera and Pectinaria sp. (Fig. 11).

The age of the isolation of the basin is established as ca. 9000 cal. yr BP (Table 2) on the basis of a bulk sediment sample at the isolation contact at $1197 \mathrm{~cm}(8600-9300 \mathrm{cal}$. yr BP). The transgression is determined to have occurred sometime between $8140 \mathrm{cal}$.yr BP and $2300 \mathrm{cal}$. yr BP on the basis of the bulk sediment sample taken from both above the hiatus at $1179-1180 \mathrm{~cm}$ and below the hiatus at $1186 \mathrm{~cm}$ (Table 2).

\section{Tidal basin $\mathrm{N} 30\left(\mathrm{~N} 60.0408^{\circ}, \mathrm{W} 44.9033^{\circ}\right)$}

This tidal basin is also located ca. $23 \mathrm{~km}$ southeast of Nanortalik north east of the island of Narlusoq and measures ca. $500 \times 200 \mathrm{~m}$. The threshold, situated at an altitude of ca. 


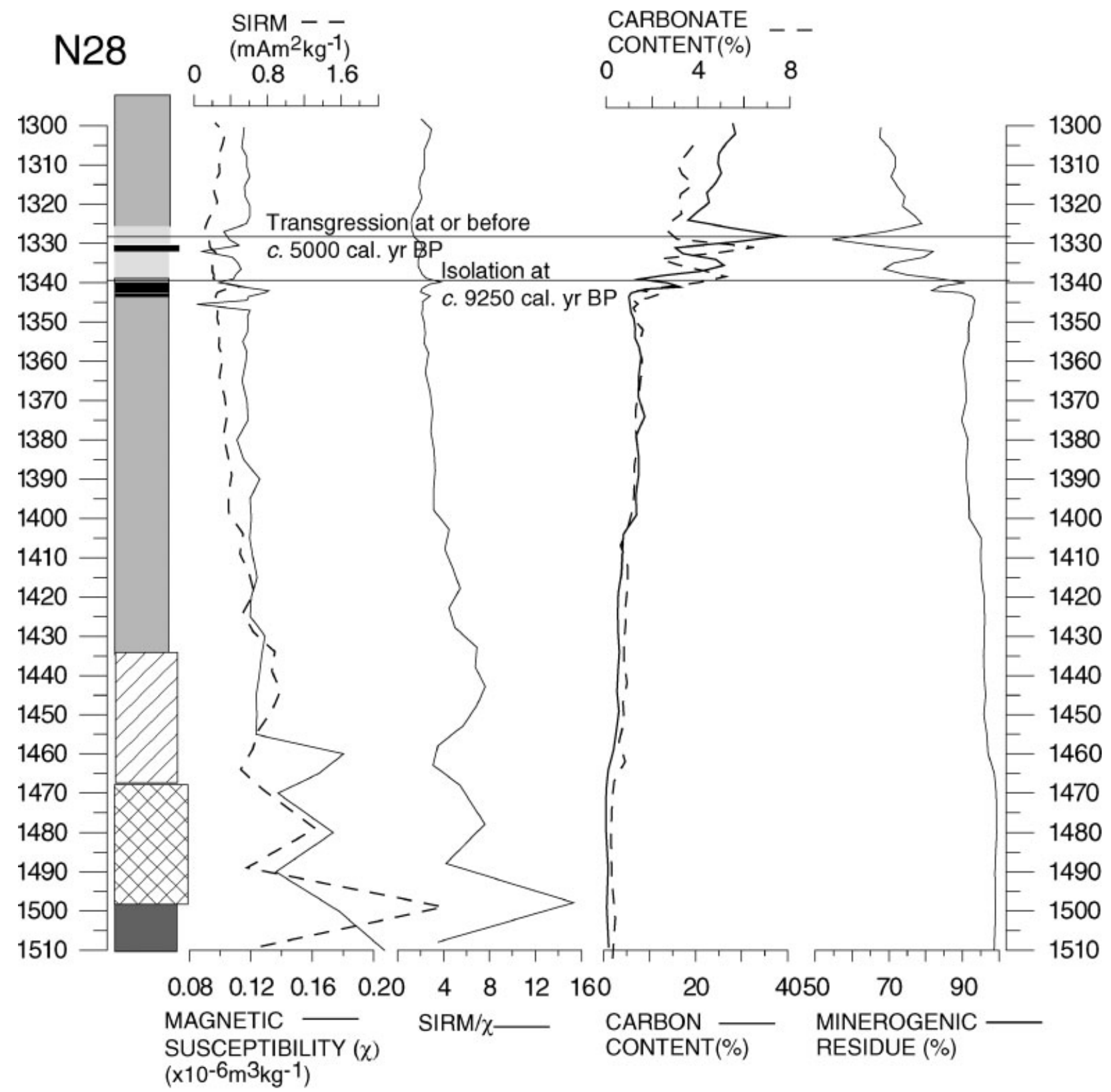

\section{Legend}

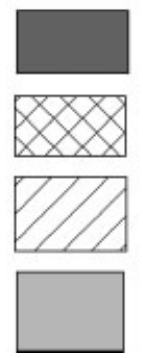

Grey clayey sandy silt

Silty gravelly and clayey silty sand

\section{Sandy clayey gyttja silt} Clayey to sandy silt gyttja

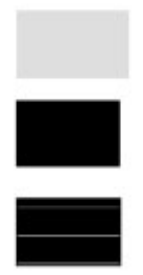

Sandy and silty algae gyttja

Gyttja sand

FeS-laminated sandy clayey algaerich silt gyttja

Figure 8 Core log for site N28, the magnetic susceptibility, dry SIRM/ $\chi$ (scale bar on top), dry SIRM, carbon contents (mass\% of dry weight), carbonate contents (mass\% of dry weight, scale bar on top) and minerogenic residue (mass \% of dry weight). Ages given are cal. yr BP or interpreted interpolated ages between several dates

$0.6 \mathrm{~m}$ b.h.a.t., is made up of boulders and the maximum depth in the rather shallow basin was measured to around $2.6 \mathrm{~m}$. The water depth at the coring site was measured to ca. $0.8 \mathrm{~m}$ and as the coring was done during low tide, no variations in depth at the coring site were registered. The isolation contact is placed at $139.5 \mathrm{~cm}$ at the transition from greenish brown sandy clayey silty gyttja to brown sandy silty algal rich gyttja (Fig. 12). Below the isolation contact Tricladida indet. dominates the environment, but disappear above this level and a freshwater flora and fauna with Cladocera, Chironomidae and Isoëtes lacustris takes over (Fig. 13).

Both the organic carbon and carbonate content increase at the isolation contact level. The magnetic susceptibility (Fig. 12) decreases at the isolation contact while the SIRM measurements show little change. The transgression, with a first marine incursion seen from macrofossil analyses at $112 \mathrm{~cm}$, was gradual and the sediments change from dark brown clayey silty sandy gyttja into grey clayey silty sandy 

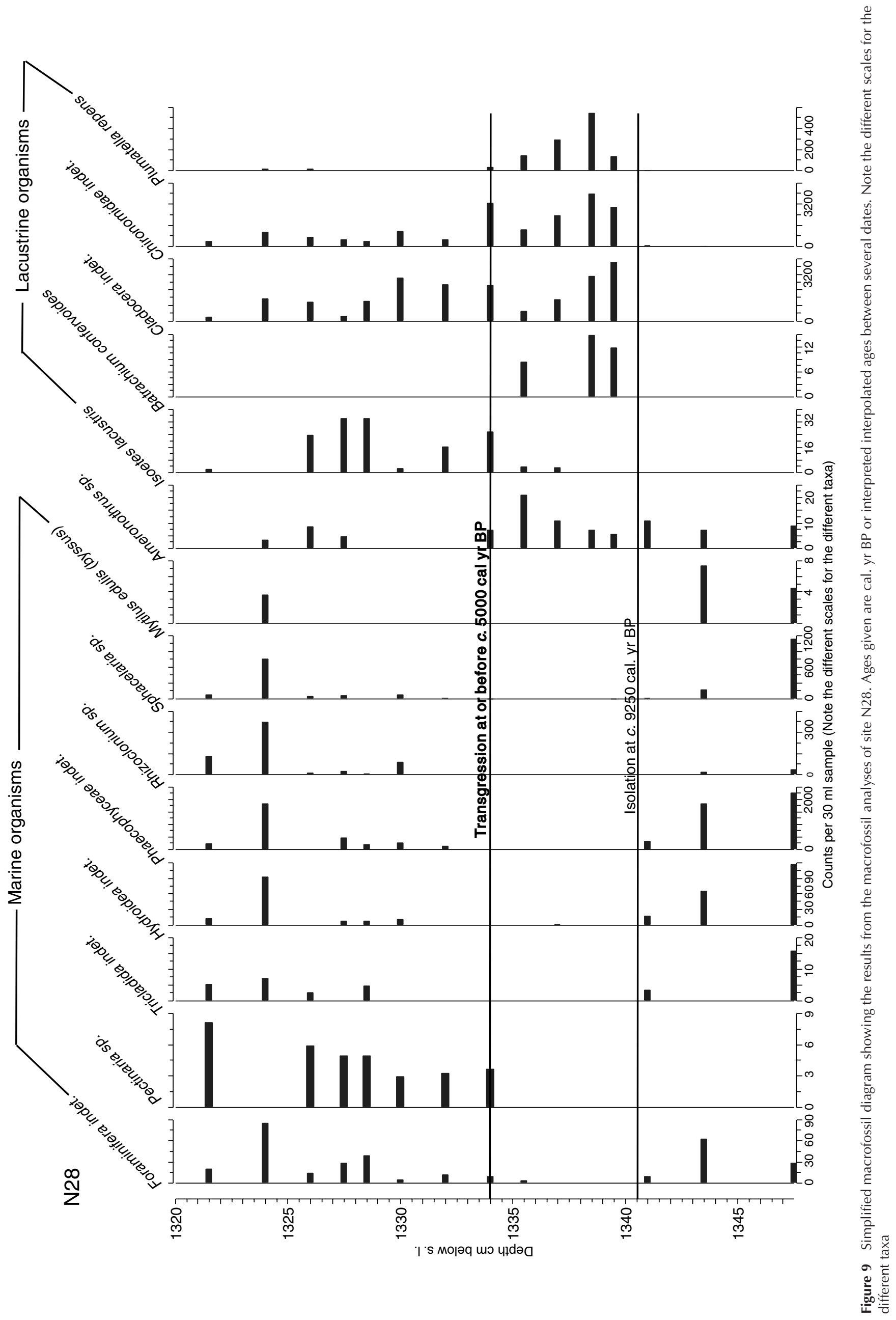


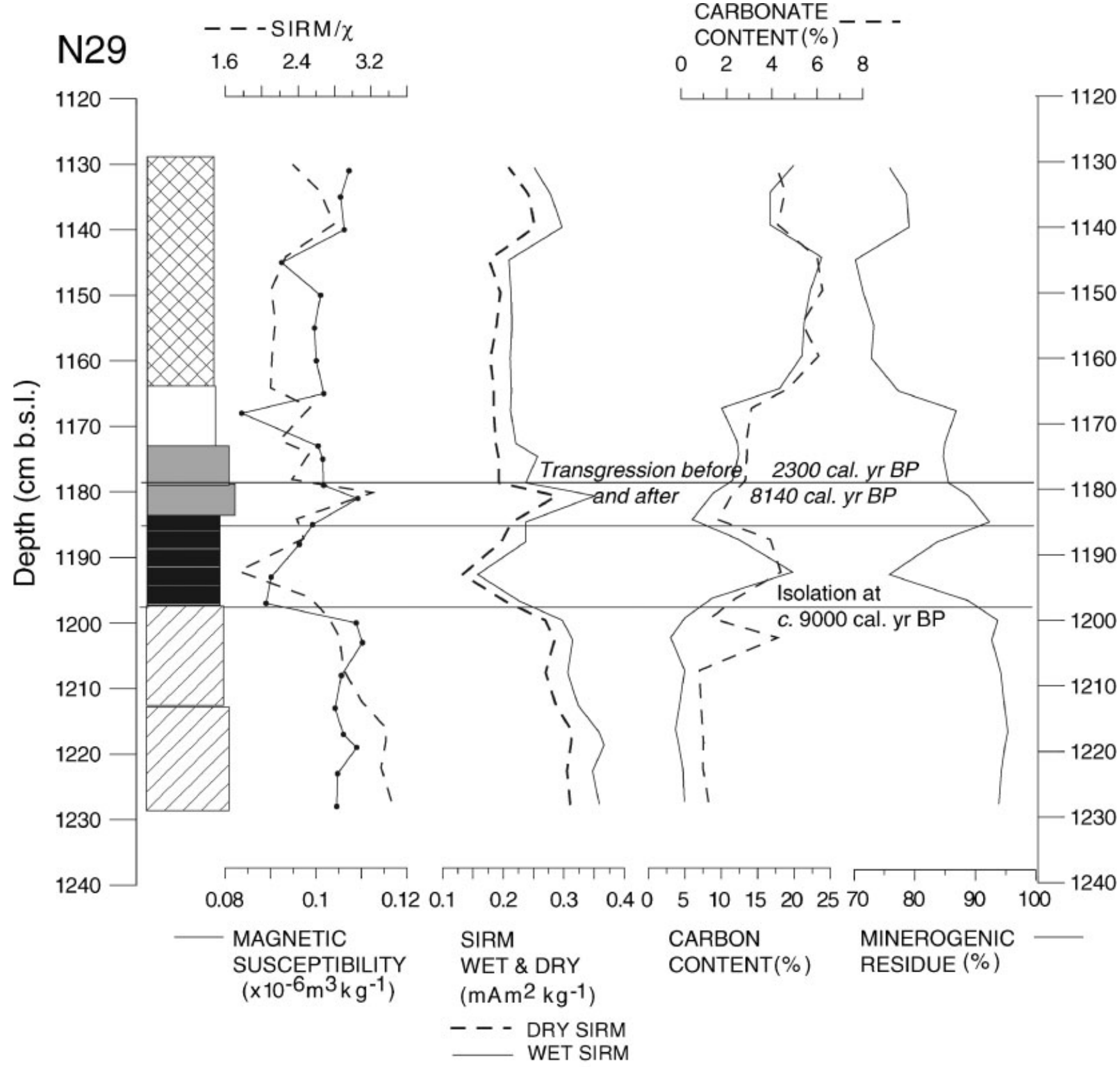

\section{Legend}

clayey sandy silt gyttja and sandy clayey silt gyttja sandy silt gyttja

clayey silty algae-rich gyttja

CARBONATE CONTENT (\%)

$\begin{array}{lllll}0 & 2 & 4 & 6 & 8\end{array}$

Figure 10 Core log for site N29, the magnetic susceptibility, SIRM/ $\chi$ (scale bar on top), SIRM wet and dry, carbon contents (mass $\%$ of dry weight), carbonate contents (mass\% of dry weight, scale bar on top) and minerogenic residue (mass\% of dry weight). Ages given are cal. yr BP or interpreted interpolated ages between several dates

gyttja with visible shell fragments. The macrofossil analyses show that Pectinaria sp. and Macoma balthica enter the basin at $112 \mathrm{~cm}$ while at the same time Cladocera, Chironomidea and Isoëtes lacustris decrease in numbers (Fig. 13). The freshwater flora and fauna almost totally disappear at ca. $102-104 \mathrm{~cm}$.

The age of the isolation of the basin is established to ca. 9300 cal.yr BP (9130-9530 cal. yr BP) (Table 2) based on a macrofossil sample containing Empetrum nigrum and Hippuris vulgaris from $139 \mathrm{~cm}$ depth. The time of transgression is determined to ca. 900 cal. yr BP from a macrofossil sample, contain- ing Juniperus communis and Empetrum nigrum, taken at $113 \mathrm{~cm}$, just below the first marine incursion (Table 2).

\section{Discussion}

\section{Basin isolation}

In the Nanortalik area, early Holocene isolation sequences show abrupt lithological changes from coarser minerogenic sediments deposited in a (glacio-) marine environment forming 


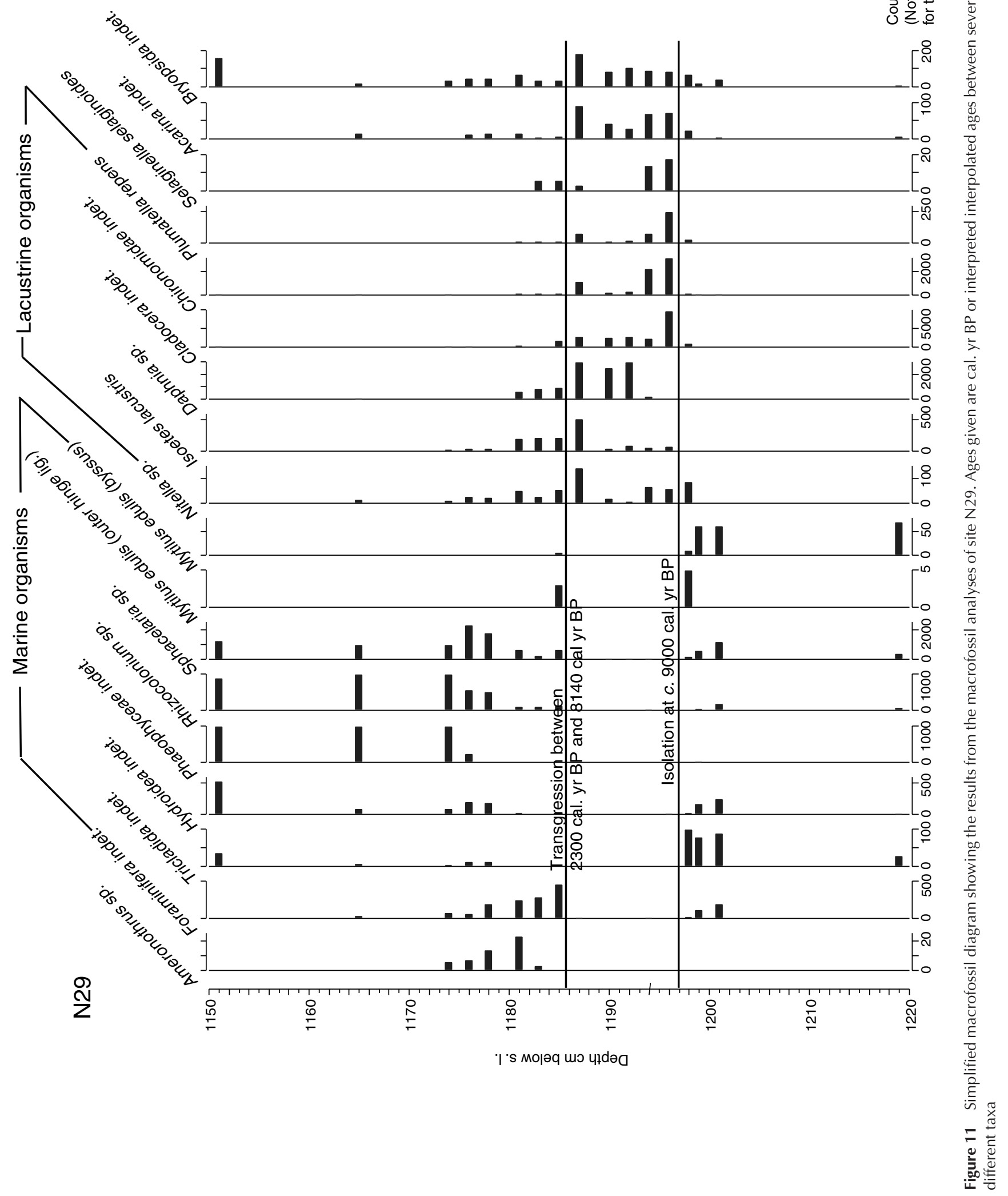




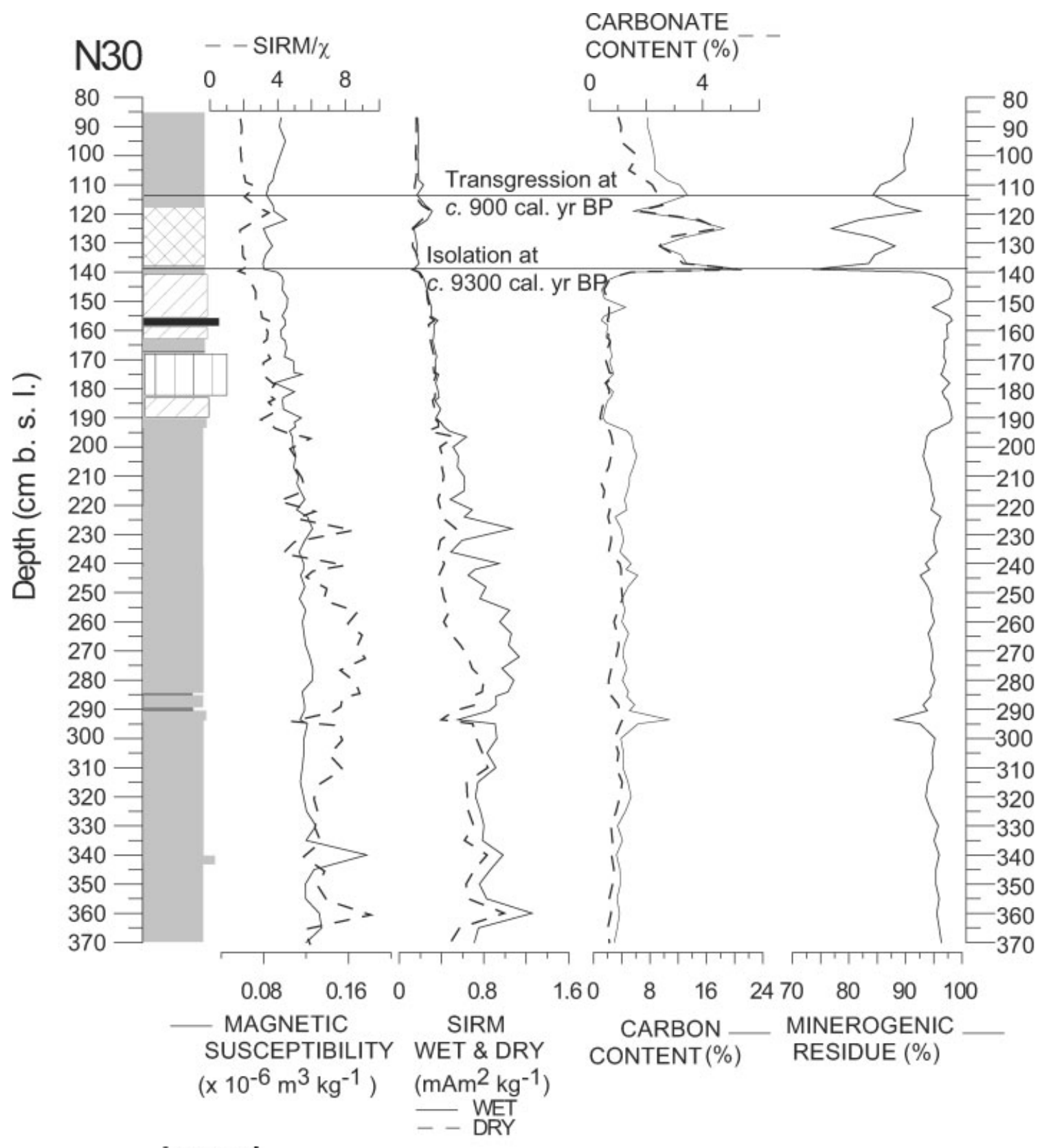

\section{Legend}

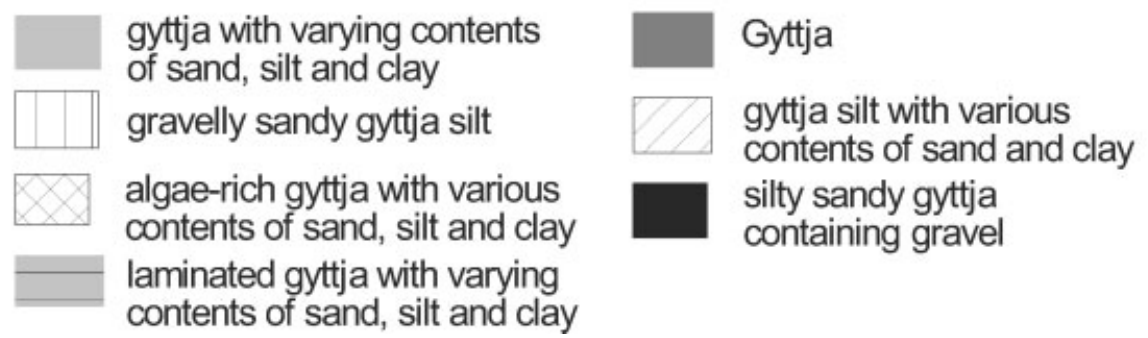

Figure 12 Core log for site N30, the magnetic susceptibility, SIRM/ $\chi$ (scale bar on top), SIRM wet and dry, carbon contents (mass\% of dry weight), carbonate contents (mass \% of dry weight, scale bar on top) and minerogenic residue (mass\% of dry weight). Ages given are cal. yr BP or interpreted interpolated ages between several dates

laminated sediment, often with black iron sulphide-rich laminations deposited in a brackish water environment, and often shifting abruptly into a freshwater deposited brownish algae gyttja. The macrofossil analyses show that pre-isolation sediments are dominated by marine brown algae such as Sphacelaria sp., Rhizoclonium sp. and Desmarestia sp., Foraminifera, the blue mussel Mytilus edulis, hydrozoans of the order Hydro-

Copyright @ 2006 John Wiley \& Sons, Ltd. idea and flatworms of the order Tricladida. Even tiny bones of the small fish Gasterosteus aculeatus have been found in one of the basins below the isolation contact. In connection with isolation and transgression sequences, the oribatid mite Ameronothrus lineatus appears in the transitional sediments, possibly favoured by the changes between marine and lacustrine conditions. This oribatid lives at or near the sea shore (Hammer, 

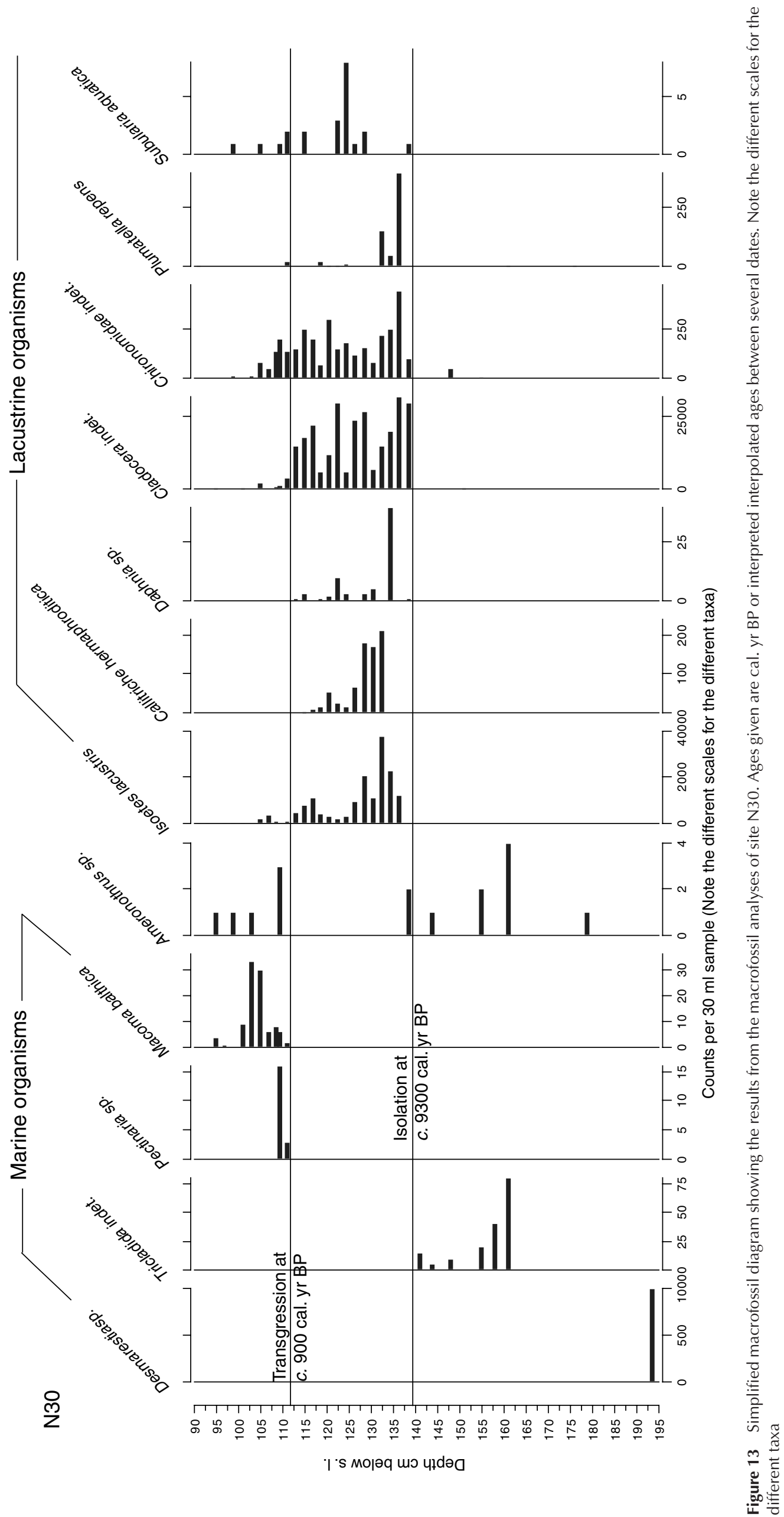
1944) and has been reported from isolation sequences before by, for example, Bennike (1992, 1995) and Bennike et al. (2002). The presence of marine organisms often ends abruptly at the isolation contact, to be replaced quickly by freshwater taxa. Most of the freshwater taxa probably arrive at the isolated lake by surface runoff from small rivers, draining lakes further inland, but some species may also be transported by birds. The most commonly found freshwater organisms are cladocerans like Daphnia sp. and Alona sp., Chironomids, Isoëtes lacustris, Nitella sp., Plumatella repens, Rhabdocoela flatworms, the water-crowfoot Batrachium confervoides, larval cases from Trichoptera, some Hippuris vulgaris and Lepidurus arcticus. Occasional bones from the fish Gasterosteus aculeatus have also been found above the isolation contact from site N26.

\section{Basin ingression}

The transition from freshwater sediments into marine sediments is often not as clearly visible as the isolation contacts. This is a consequence of the gradient of the sea-level change being high during the isolation and lower during the transgression. It is usually obvious in the sediments that a marine ingression occurs, but in most cases macrofossil analyses were necessary to establish exactly where to place it. The changes in the sediments are more gradual than during the isolation and it is therefore difficult to define a 'transgression contact'. Physically, the change is often seen as a higher amount of mineral particles, which often but not always shows up as higher magnetic susceptibility and higher SIRM values; in fact, biogenic magnetite can give higher signals than minerogenic sediments. In some cases, as in sites N28 and N29, the in- and out-flowing tidal currents have eroded parts of the sedimentary column during the marine ingression. The macrofossil analyses have shown that the environmental change is gradual with several marine species showing up in small numbers at the same time as freshwater species gradually decline in numbers of individuals. It is not unusual to find both marine and freshwater species in fairly large numbers in the first $10-15 \mathrm{~cm}$ of the sediment column above the registration of the first marine ingression. The marine taxa that first migrate into the basins are often Foraminifera, brown algae such as Sphacelaria sp., Rhizoclonium sp. and Desmarestia sp., bivalves such as Mytilus edulis or Macoma balthica, hydrozoans of the order Hydroidea, the ice-cream-cone worm Pectinaria and flatworms of the order Tricladida. Remains of the marine fish Mallotus villosus have been found in the transgression sequence of N25 and in fully marine sediments in N28.

\section{A Lateglacial and Holocene sea-level curve from the Nanortalik area}

The isolation and transgression ages shown in Fig. 14 are a summary of the seven sites from Bennike et al. (2002) (Table 3) and the six sites described in this paper. The sea levels shown are the inferred values for the individual sites and no adjustment has been made for possible differential isostatic signals between sites that do not lie on the same isobase for the reason that the orientation and gradient of the isobases cannot be determined with accuracy from the available data. The sites $\mathrm{N} 16, \mathrm{~N} 18, \mathrm{~N} 19, \mathrm{~N} 21, \mathrm{~N} 22, \mathrm{~N} 24, \mathrm{~N} 28, \mathrm{~N} 29$ and N30 are at very comparable distances from the present ice margin and from the shelf edge and differential isostatic signals for these sites are likely to be small. The oldest isolation basin (site N14) also lies further offshore and its elevation would be increased if projected onto a sea-level curve for the main cluster of sites. Therefore Fig. 14 should not be interpreted as a sea-level curve for any specific location but as a general representation of change over the area spanned by the data points.

All ages are calibrated to yr BP using OxCal (v. 3.9) with $2 \sigma$ error bars, with the exception of the transgression age of basin $\mathrm{N} 27$ for which the age is the result of an interpolation between dates above and below the transgression as discussed above. The altitude error bars are based on the total uncertainty presented in Table 1. No basins suitable for coring with thresholds below $-7.8 \mathrm{~m}$ b.h.a.t. have been found in the area and we cannot establish firmly the maximum lowest Holocene sea level attained in the area. The sediments from sites N28 and N29 show erosive contacts (i.e. hiatuses) and this implies a dynamic environment with strong bottom currents eroding the soft gyttja sediments and could indicate, especially for site N28 where the threshold is wide, that the lowest sea level in the area was close to this threshold altitude. The fact that marine macrofossils are found in the sediment column from N25 during a freshwater-dominated period, could also imply that sea level was close to the threshold and that marine sediments were washed in during storm events. Thus the lowest sea level in the Nanortalik region could not have been much lower than ca. $10 \mathrm{~m}$ below highest astronomical tide and occurred between 8000 and 6000 cal. yr BP (Fig. 14). The observations presented in Fig. 14 show a slow regression between 14000 and $12000 \mathrm{cal} . \mathrm{yr} \mathrm{BP}$ and an accelerated regression between 12000 and $9000 \mathrm{cal}$.yr BP. This implies a fast recession of the ice sheet during at least parts of the Lateglacial and the early Holocene. The slower transgression starting at sometime before $5000 \mathrm{cal}$.yrBP could reflect either a readvance of the Greenland ice sheet and/or a delayed collapse of the Laurentide peripheral bulge. It has been suggested that the ice sheet margin reached its present position at around 9500 $\mathrm{BP}$, and from $9000 \mathrm{BP}$ to $3000 \mathrm{BP}$ the ice margin was behind this position (Weidick et al., 2004). This suggestion correlates very well with the sea-level observations presented here, as sea level fell below the present at around $9300 \mathrm{cal}$. yr BP and then rose from around the mid-Holocene to reach the present level fairly recently. Neoglacial growth and/or a delayed isostatic response to the changes in the Laurentide and/or the Greenland ice sheets can explain such behaviour in relative sea level. It could also be a combination of both processes.

The data in the diagram in Fig. 14 are uncorrected for differential isostatic rebound and should be seen as raw data and not as a relative sea-level curve for any specific locality. We are currently working on relative sea-level changes in a second area of southern Greenland (Qaqortoq-Narsarsuaq). When this analysis is completed we will be in a better position to establish the gradients and rates of crustal rebound and to draw conclusions about ice thickness and ice margin locations for the Lateglacial period. This work is important as observations of relative sea-level changes in southern Greenland are few and provide few constraints for glacial-isostatic adjustment models. Poor agreement is seen between results from glacial-isostatic adjustment models reconstructing sea-level and glacial history with those few observations available at present (Bennike et al., 2002; Tarasov and Peltier, 2002; Fleming and Lambeck, 2004). Fleming and Lambeck (2004) present a curve for the Kap Farvel area that shows a predicted relative sea-level rise for the entire Lateglacial and Holocene, and conclude that their model underestimates the amounts of ice melted from the region. This conclusion agrees well with our observations. Tarasov and Peltier (2002) produce a curve for the Julianehåb area showing a transgression from the LGM until around $10000 \mathrm{BP}$, when the presented relative sea-level curve reaches almost $60 \mathrm{~m}$ a.s.l. 


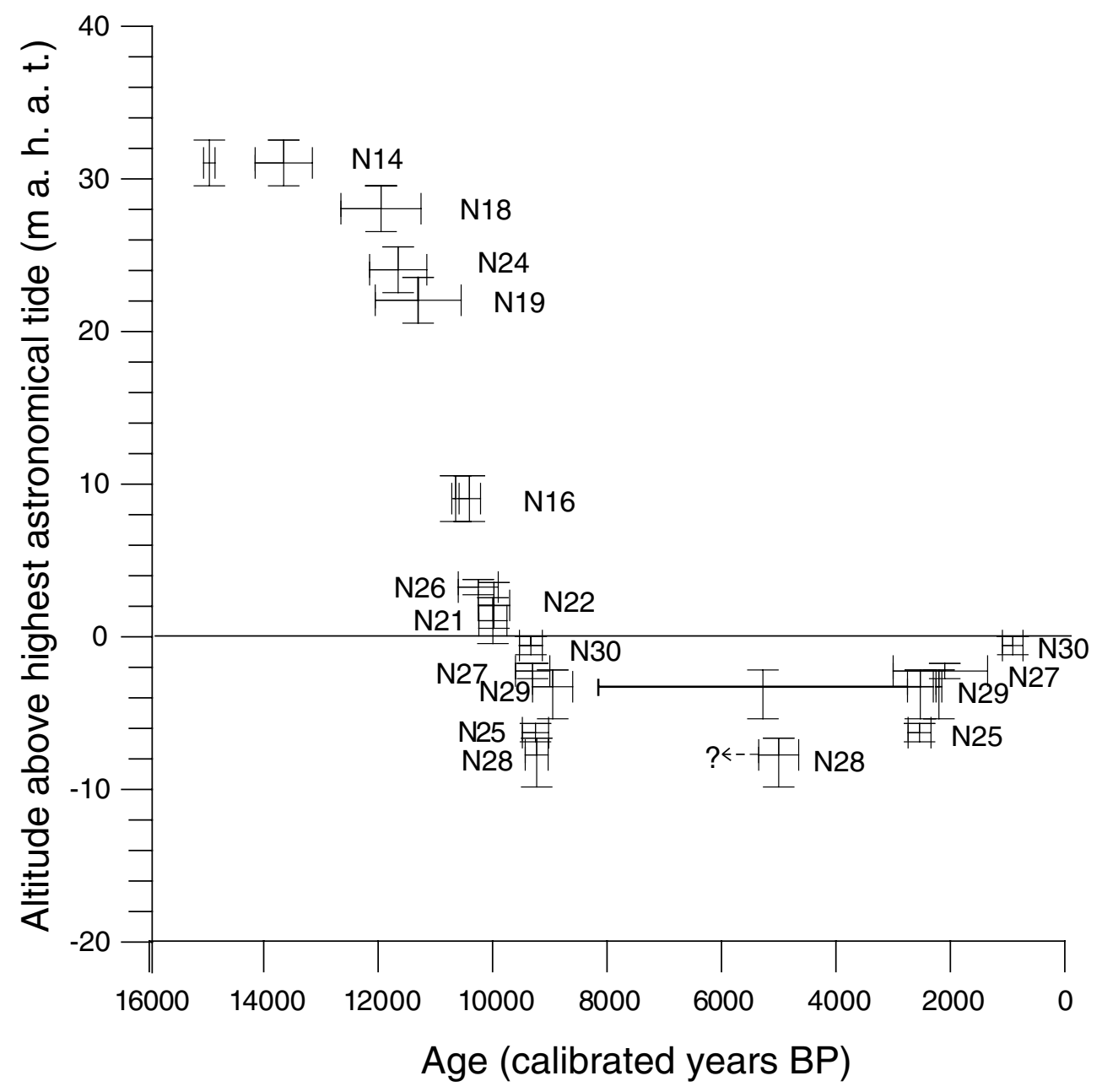

Figure 14 Relative sea-level changes in the Nanortalik area during the Lateglacial and Holocene as indicated by isolation and transgression ages of 13 different basins. Altitude errors are listed in Table 1 and age error bars of $2 \sigma$ are shown as given in Table 2. Note that some age spans are divided into two or three periods. Note also that the transgression for site N29 is dated by two samples on each side of a hiatus and shows a large span for this reason. The transgression age for site N28 is a minimum date, taken from a sample above a hiatus in marine sediments

Table 3 Selected AMS radiocarbon ages from the basins studied by Bennike et al. (2002)

\begin{tabular}{|c|c|c|c|c|c|c|}
\hline Site & Laboratory no. & Depth (cm) & Age ${ }^{14} \mathrm{C}$ yr BP & $\begin{array}{c}\text { Calibrated age } \\
2 \sigma(95.4 \%) \text { OxCal v. } 3.9\end{array}$ & Material & Comments \\
\hline N14 & Ua-14844 & $765-771$ & $11665 \pm 125$ & $\begin{array}{l}14850-15050(2.3 \%) \\
13150-14150(93.1 \%)\end{array}$ & Bryum sp. & Isolation \\
\hline N18 & Ua-15414 & $367.5-370$ & $10200 \pm 110$ & $11250-12650$ & Daphnia pulex & Isolation \\
\hline N24 & Ua-15902 & 262 & $10015 \pm 120$ & $11150-12150$ & Bulk & Above isolation \\
\hline N19 & Ua-15417 & $793-796$ & $9810 \pm 175$ & $10550-12050$ & Warnstorfia exannulata & Above isolation \\
\hline N16 & Ua-15412 & $589-591.5$ & $9240 \pm 95$ & $\begin{array}{l}10610-10680 \\
10210-10600\end{array}$ & $\begin{array}{l}\text { Batrachium confervoides, } \\
\text { Empetrum nigrum }\end{array}$ & Isolation \\
\hline N22 & Ua-15419 & $1125-1128$ & $8905 \pm 90$ & $9700-10250$ & $\begin{array}{l}\text { B. confervoides, Hippuris vulgaris, } \\
\text { E. nigrum, Bryum sp., W. exannulata }\end{array}$ & Above isolation \\
\hline N21 & Ua-15418 & $700-704.5$ & $8930 \pm 80$ & 9750-10240 & B. confervoides, E. nigrum & Isolation \\
\hline
\end{tabular}

From 10000 years BP and onwards the curve shows a regression that continues until the present. Tarasov and Peltier (2002) compare their modelled relative sea-level curve for south Greenland to a single observation and because this one point does not match their model prediction, they suspect the observation to be erroneous. Their model prediction does not show much resemblance to the observations presented in this work either, implying that their model needs to be modified. In Bennike et al. (2002) the analysis is more extensive for the area because it deals only with southern Greenland. Even though the comparison between the observations and the predictions are unsatisfactory, they conclude that the model underestimates the reduction in ice thickness and that the timing of the recession needs to be considered in more detail. The 
analyses imply rapid melting before the earliest isolations and this conclusion agrees well with our observations. Observational data from only one area will not give a unique solution and it is therefore important that more data are collected before new extensive modelling analyses can be made.

\section{Conclusions}

Holocene relative sea-level changes in southern Greenland have previously been observed mostly on land and in lakes and they indicate that levels were below present sea-level for the past $10000 \mathrm{yr}$. In this paper we present evidence that the local sea-level reached $\sim 10 \mathrm{~m}$ below highest astronomical tide (slightly lower than $7.8 \mathrm{~m}$ b.h.a.t.) in the interval from 8000 to $6000 \mathrm{cal}$. yr BP. Combined with earlier results we can draw the following conclusions about sea-level changes in the Nanortalik area of southern Greenland:

1. The relative sea-level fall in the early Holocene was rapid from the time the area became ice-free, whereas the relative sea-level rise in the mid- to late Holocene was slower and more gradual.

2. The fall in sea level between 12000 and 10200 cal.yr BP shown by Bennike et al. (2002) continued until at least 9000 cal.yr BP, by which time sea level reached below $-7.8 \mathrm{~m}$ b.h.a.t. and continued to fall some time after that. The relative uplift of the area during that time was ca. $12 \mathrm{~mm} \mathrm{yr}^{-1}$.

3. Between 8000 and $6000 \mathrm{cal}$. yr BP, sea level in the Nanortalik area reached its lowest level at around $10 \mathrm{~m}$ b.h.a.t.

4. During the mid-Holocene, at or before ca. 5000 cal. yr BP, sea level again reached above $-7.8 \mathrm{~m}$ b.h.a.t. and continued to slowly rise until the present day. The mean submergence of the area during this time was $1.5-2 \mathrm{~mm} \mathrm{yr}^{-1}$.

Our results explain why Norse ruins are found so close to the present shore (Bak, 1969); because since the Norse people built their houses around 1000 years ago, relative sea level has risen ca. 0.5-1 m. Also, evidence for the presence of Palaeo-Eskimo cultures is extremely rare in southern Greenland. The lack of Palaeo-Eskimo ruin sites is not necessarily evidence of their absence. If these early Palaeo-Eskimos reached Greenland, settlements are likely to be found below present sea level because local sea level has risen 5-6 m since $4000 \mathrm{cal}$. yr BP. The question remains Did Palaeo-Eskimo cultures reach this part of Greenland? If so, has the evidence been preserved, or have tidal currents and wave action destroyed them?

Acknowledgements We thank the Carlsberg Foundation and the Crafoord Foundation for all funding that made this study possible, and the Swedish Polar Research Council for their logistic support. Kurt Lambeck thanks the Swedish Research Council for the financial support as Tage Erlander Professor. We also acknowledge Vasile Ersek and Niklas Sparrenbom for all their work and help in the laboratory, Dr Kevin Fleming for fruitful discussions on geodynamics, Palle Bo Nielsen at Farvandsvæsenet for making tidal charts easily accessible and discussions on tidal issues, Ole Andersen at Kort \& Matrikelstyrelsen for calculating the astronomical tides, Dr Göran Skog and Dr hab. Tomasz Goslar for help and discussion about radiocarbon ages, Professor Mats Sonesson for help in identifying moss remains from the cores, Dr Poul Møller Pedersen for help with identification of algae, Dr Lena Barnekow and Professor Gunnar Digerfeldt for support in identifying macrofossils and all others that in any way have contributed to making this investigation successful. Last but not least we would like to express our gratitude to Morten
Rasch and the anonymous reviewer who helped improve the manuscript.

\section{References}

Bak O. 1969. Herjolfsnæs. Grønland 1969: 349-352.

Bennike O. 1992. Palaeoecology and paleoclimatology of a late Holocene peat deposit from Brændevinsskær, central West Greenland. Arctic and Alpine Research 24: 249-252.

Bennike O. 1995. Palaeoecology of two lake basins from Disko, West Greenland. Journal of Quaternary Science 10: 149-155.

Bennike O. 2002. Late Quaternary history of Washington Land, North Greenland. Boreas 31: 260-272.

Bennike O, Weidick A. 2001. Late Quaternary history around Nioghalvfjerdsfjorden and Jøkelbugten, North-East Greenland. Boreas 30: 205-227.

Bennike O, Björck S, Lambeck K. 2002. Estimates of South Greenland late-glacial ice limits from a new relative sea level curve. Earth and Planetary Science Letters 197: 171-186.

Björck S. 1979. Late Weichselian stratigraphy of Blekinge, SE Sweden, and water level changes in the Baltic Ice Lake. LUNDQUA Thesis 7, 248 pp.

Björck S, Persson T. 1981. Late Weichselian and Flandrian biostratigraphy and chronology from Hochstetter Forland, Northeast Greenland. Meddelelser om Grønland, Geoscience 5: 19.

Björck S, Bennike O, Ingólfsson Ó, Barnekow L, Penney DN. 1994. Lake Boksehandsken's earliest postglacial sediments and their palaeoenvironmental implications, Jameson Land, East Greenland. Boreas 23: 459-472.

Bronk Ramsey C. 2001. Development of the radiocarbon program OxCal. Radiocarbon 43: 355-363.

Escher A, Watt WS. 1976. Summary of the geology of Greenland. In Geology of Greenland, Escher A, Watt WS (eds). The Geological Survey of Greenland: Copenhagen; 10-16.

Farvandsvæsenet. 2000. Tidevandstabeller 2001 for Grønlandske Farvande. Farvandsvæsenet: Copenhagen.

Farvandsvæsenet. 2001. Tidevandstabeller 2002 for Grønlandske Farvande. Farvandsvæsenet: Copenhagen.

Fleming K, Lambeck K. 2004. Constraints on the Greenland Ice Sheet since the Last Glacial Maximum from sea-level observations and glacial-rebound models. Quaternary Science Reviews 23: 1053-1077.

Fredskild B. 1973. Studies in the vegetational history of Greenland, palaeobotanical investigations of some Holocene lake and bog deposits. Meddelelser om Grønland 198(4): 245.

Funder S. 1978. Holocene stratigraphy and vegetation history in the Scoresby Sund area, East Greenland. Bulletin Grønlands Geologiske Undersøgelse no. 129; 66 pp.

Funder S. 1979. The Quaternary geology of the Narssaq area, South Greenland. Rapport Grønlands Geologiske Undersøgelse no. 86; $24 \mathrm{pp}$.

Gabel-Jørgensen CCA, Egedal J. 1940. Tidal observations made at Nanortalik and Julianehåb in 1932-1934. Meddelelser om Grønland 107(2): 47.

Hammer M. 1944. Studies on the Orbatids and Collemboles of Greenland. Meddelelser om Grønland 141(3): 210.

Kelly M, Funder S, Houmark-Nielsen M, Knudsen KL, Kronborg C, Landvik J, Sorby L. 1999. Quaternary glacial and marine environmental history of northwest Greenland: a review and reappraisal. Quaternary Science Reviews 18: 373-392.

Kuijpers A, Abrahamsen N, Hoffman G, Hühnerbach V, Konradi P, Kuzendorf H, Mikkelsen N, Thiede J, Weinrebe W, shipboard scientific party of RV Poseidon, surveyors of the Royal Danish Administration for Navigation and Hydrography 1999. Climate change and the Viking-age environment of the Eastern Settlement, South Greenland. Geology of Greenland Survey Bulletin 183: 61-67.

Lambeck K, Chappell J. 2001. Sea level change through the last glacial cycle. Science 292: 679-686.

Long AJ, Roberts DH. 2002. A revised chonology for the 'Fjord Stade' moraine in Disko Bugt, west Greenland. Journal of Quaternary Science 17: 561-579. 
Long AJ, Roberts DH, Rasch M. 2003. New observations on relative sea level and deglacial history of Greenland from Innaarsuit, Disko Bugt. Quaternary Research 60: 162-171.

Long AJ, Roberts DH, Wright MR. 1999. Isolation basin stratigraphy and Holocene relative sea-level change on Arveprinsen Ejland, Disko Bugt, West Greenland. Journal of Quaternary Science 14: 323-345.

Mathiassen T. 1936. The eskimo archaeology of Julianehaab District. Meddelelser om Grønland 118(1): 141.

Rasch M. 2000. Holocene relative sea level changes in Disko Bugt, West Greenland. Journal of Coastal Research 16: 306-315.

Rasch M, Jensen JF. 1997. Ancient Eskimo dwelling sites and Holocene relative sea level changes in southern Disko Bugt, central West Greenland. Polar Research 16: 101-115.

Rasch M, Holm Jakobsen B, Nielsen N. 1997. Geomorphology and sedimentary record of three cuspate forelands as indicators of late
Holocene relative sea-level changes, Disko, West Greenland. Danish Journal of Geography 97: 33-46.

Sandgren P, Snowball I. 2001. The Late Weichselian sea level history of the Kullen Peninsula in northwest Skåne, southern Sweden. Boreas 30: 115-130.

Stuiver M, Reimer P, Bard E, Beck WJ, Burr GS, Hughen KA, Kromer B, McCormac G, van der Plicht J, Spurk M. 1998. INTCAL 98 radiocarbon age calibration, 24,000-0 cal. BP. Radiocarbon 40: 1041-1083.

Tarasov L, Peltier WR. 2002. Greenland glacial history and local geodynamic consequences. Geophysical Journal International 150: 198-229.

Walden J, Oldfield F, Smith JP (eds). 1999. Environmental Magnetism: A Practical Guide. Technical Guide, No. 6. Quaternary Research Association: London; 243 pp.

Weidick A, Kelly M, Bennike O. 2004. Late Quaternary development of the southern sector of the Greenland Ice Sheet, with particular reference to the Qassimiut lobe. Boreas 33: 284-299. 